BARRY BOSWORTH

Brookings Institution

GARY BURTLESS

Brookings Institution

JOHN SABELHAUS

Towson State University

\title{
The Decline in Saving: Evidence from Household Surveys
}

THE RATE of national saving in the United States declined precipitously in the 1980s. From World War II to 1980 the net saving rate averaged 8 percent of national income; today the rate is just 2 percent. While much public discussion has focused on the growth in the federal budget deficit as a source of this decline, a larger part of the drop in saving has come from a falloff in the rate of private saving.

The extent of decline in the private saving rate is a surprise for several reasons. The slide comes after several decades in which the saving rate fluctuated within a very narrow range. The narrowness of that range inspired many economists to treat the private saving rate as an uninteresting constant. Second, the largest part of the decline occurred, ironically, after the government made an increase in saving a major objective of economic policy and redesigned the tax system to increase effective after-tax rates of return and promote saving. Finally, the decline coincided with a dramatic increase in real market interest rates, which should have greatly strengthened saving incentives.

Economists have no shortage of theories to explain the decline in saving. Given the previous stability of the saving rate and the one-time nature of the decline, however, it is virtually impossible to sort out the

The authors gratefully acknowledge the suggestions of Michael Cohen of the University of Maryland and the research assistance of Suzanne Smith and Paul Bergin. 
conflicting explanations on the basis of macroeconomic data alone. This paper reports on some empirical explorations of household survey data to determine if microeconomic analysis can provide any insight into the source of the decline. Specifically, we use the survey data to evaluate the validity of some recent explanations for reduced saving.

An ideal data set would contain information from a panel survey that followed a representative group of households continuously throughout the period of the decline. No such survey data currently exist. ${ }^{1}$ Thus we have explored a second approach-comparing similar surveys conducted before and after the collapse in private saving. To supplement the analysis of U.S. data, we consider results from similar microeconomic surveys in Canada and Japan, where private saving has also declined. Although this approach does not permit us to follow individual households, we can observe the change in saving behavior among households with similar characteristics. Among the potential explanations that we examine for the saving decline are changes in the demographic structure of the population, changes in the distribution of income, and the influence of capital gains in real-estate and financial assets.

\section{Aggregate Trends in Saving}

The magnitude of the decline in U.S. saving is shown in table 1. Most numbers in the table are drawn directly from the national income accounts (NIA). However, we have reclassified the accumulation of reserves in the funded pension programs of state and local government employees. In the national accounts the accumulation of reserves in state and local pension plans is classified as government saving. We believe the accumulation seems more analogous to similar accumulations in private pension programs, which are classified as the saving of workers. The pension contributions on behalf of state and local government employees raise compensation and pension wealth in the same fashion as the contributions to private pension plans. In the table we therefore count state and local pension accumulations as part of private

1. The Survey of Consumer Finances does contain information on wealth accumulation from a sample of households over two intervals, from 1983 to 1986 and from 1986 to 1989. Unfortunately, these data do not permit us to analyze the sample's saving behavior during the period before the early 1980s when household saving was comparatively high. Moreover, the data from the 1989 reinterview will not be available until late 1991. 
Table 1. Annual Rates of Net Saving and Investment, United States, 1951-90

Percent

\begin{tabular}{|c|c|c|c|c|c|c|}
\hline Item & $1951-60$ & $1961-70$ & $1971-80$ & $1981-85$ & $1986-90$ & 1990 \\
\hline $\begin{array}{l}\text { Total national saving } \\
\text { (investment) }\end{array}$ & 8.0 & 8.4 & 7.7 & 3.7 & 2.0 & 1.7 \\
\hline Net saving & & & & & & \\
\hline $\begin{array}{l}\text { Private saving }{ }^{\mathrm{a}} \\
\text { Government saving }\end{array}$ & $\begin{array}{r}8.6 \\
-0.7\end{array}$ & $\begin{array}{r}9.5 \\
-1.0\end{array}$ & $\begin{array}{r}9.6 \\
-2.0\end{array}$ & $\begin{array}{r}8.1 \\
-4.5\end{array}$ & $\begin{array}{r}6.3 \\
-4.0\end{array}$ & $\begin{array}{r}5.6 \\
-4.0\end{array}$ \\
\hline $\begin{array}{l}\text { Net investment } \\
\text { Net domestic investment } \\
\text { Net foreign investment }\end{array}$ & $\begin{array}{l}7.7 \\
0.3\end{array}$ & $\begin{array}{l}7.7 \\
0.7\end{array}$ & $\begin{array}{l}7.5 \\
0.3\end{array}$ & $\begin{array}{r}5.0 \\
-1.3\end{array}$ & $\begin{array}{r}4.8 \\
-2.8\end{array}$ & $\begin{array}{r}3.4 \\
-1.8\end{array}$ \\
\hline $\begin{array}{l}\text { Addenda } \\
\text { Capital consumption } \\
\text { allowances }^{b} \\
\text { Personal saving rate } \\
\end{array}$ & $\begin{array}{l}9.0 \\
7.2\end{array}$ & $\begin{array}{l}8.4 \\
7.6\end{array}$ & $\begin{array}{l}9.8 \\
8.9\end{array}$ & $\begin{array}{r}11.4 \\
7.6\end{array}$ & $\begin{array}{r}10.7 \\
5.8\end{array}$ & $\begin{array}{r}10.5 \\
6.2\end{array}$ \\
\hline
\end{tabular}

Source: National Income and Product Accounts. Saving and investment rates are calculated as a percent of net national product, which is equal to gross national product less capital consumption allowances. Thus, net saving and investment, which are the same by accounting convention, equal the gross flows less capital consumption allowances. Total net saving differs from total national saving by the amount of the statistical discrepancy.

a. Private saving is the saving of businesses and households. Employee pension funds of state and local governments are measured as household saving in order to match the treatment of private pension funds.

b. Capital consumption allowances are shown as a percent of gross national product.

c. The personal saving rate is shown as a percent of disposable income.

saving. ${ }^{2}$ We also report the data exclusive of capital consumption allowances because we are primarily interested in the issue of wealth accumulation. Capital consumption allowances as a share of gross domestic product (GDP) are shown at the bottom of the table for those who prefer to look at gross saving. We do not present any of the alternatives to the national accounts concept of saving that have been calculated by other economists. While a wide range of defensible adjustments could be made, other studies suggest that these adjustments would influence the measured level and cyclical behavior of the saving rate but not the extent of its secular decline. ${ }^{3}$ Using our concepts, the overall net national saving rate has fallen by about 6 percent of net

2. The pension fund adjustment is significant, since the annual accumulation of these reserves increased from 0.5 percent of net national product in 1960 to 1.2 percent in 1990. We did not make a similar adjustment for the federal pension program or social security old-age pensions because they are, for the most part, unfunded programs, although the merits of such an adjustment can be argued.

3. See, for example, Summers and Carroll (1987), Auerbach and Kotlikoff (1989), and Bradford (1990). The major alternatives for defining saving involve one or more of the following: reclassifying the net accumulation of consumer durables as saving, adjusting the value of the debt owed by governments to the private sector for the effects of inflation, and relying on the data from the Flow of Funds accounts. One exception is the issue raised by Bradford of whether private saving inclusive of capital gains has declined. That issue is taken up in a later section. 
national product (NNP), with about half of the decline originating in the government sector and half in the private sector.

In the early part of the 1980s the drop in saving had little effect on the nation's ability to finance domestic investment because there was a significant amount of idle resources and the United States attracted a surprisingly large flow of resources from the rest of the world-the current account deficit reached 3.8 percent of NNP in 1987. Recently, however, high borrowing costs and slow growth have pushed down the rate of domestic investment by about 4 percentage points, providing greater support for the argument that the low supply of saving has crowded out some domestic investment.

We have found it useful to separate the private saving rate into three major components: corporate saving and two types of personal, or household, saving - saving accumulated inside employer-provided pension programs and other "discretionary" elements of personal saving. Changes in each of these components are influenced by a distinctive set of factors. In addition, the decline in the first two components of saving requires some explanation in view of our focus on the third component in the remainder of this paper.

A detailed breakdown of the sources of decline in private saving is shown in table 2 . The most important single source of the decline in private saving is the drop in retained earnings-or saving by corporations. The recent decline in retained earnings continues a trend extending over several decades and that accelerated after 1985. The large drop during the late 1980s can be traced to substantial economic losses by financial institutions-they have had negative retained earnings since 1985. But, as shown in the bottom half of table 2, domestic corporations are also paying out a much larger proportion of their net cash flow to bond-and stockholders. If the equity holders see through the "corporate veil," we would expect them to compensate for the increased payout rate by increasing their own rate of saving. Also in table 2, one can observe that before 1980 a portion of the decline in business saving could be attributed to the declining profitability of corporate capital, but that rate of return seems to have leveled off in the 1980s: net cash flow as a percent of gross output and as a percent of tangible assets has remained relatively stable. It is also noteworthy that American corporations derive a major portion of their retained earnings from overseas operations.

As for personal saving, employer-provided pension programs, includ- 
Table 2. Components of Private Saving and Determinants of Retained Earnings, United States, 1951-90

Percent

\begin{tabular}{lrrrrrrr}
\hline \multicolumn{1}{c}{ Item } & $1951-60$ & $1961-70$ & $1971-75$ & $1976-80$ & $1981-85$ & $1986-90$ & 1990 \\
\hline Total private saving & 8.6 & 9.5 & 10.1 & 9.2 & 8.1 & 6.3 & 5.6 \\
Retained earnings & 3.0 & 3.7 & 2.6 & 2.8 & 2.0 & 1.6 & 0.7 \\
Rest of the world (net) & 0.2 & 0.3 & 0.5 & 0.6 & 0.6 & 0.5 & 0.7 \\
Domestic financial & 0.7 & 0.6 & 0.6 & 0.5 & 0.0 & -0.2 & -0.4 \\
Domestic nonfinancial & 2.2 & 2.9 & 1.5 & 1.7 & 1.4 & 1.3 & 0.4 \\
Personal saving & 5.5 & 5.8 & 7.5 & 6.4 & 6.1 & 4.7 & 5.0 \\
Private pension reserves & 0.9 & 1.2 & 1.6 & 2.3 & 2.3 & 1.0 & 0.6 \\
State and local & & & & & & & \\
$\quad$ government pensions & 0.4 & 0.5 & 0.7 & 0.9 & 1.3 & 1.4 & 1.3 \\
$\quad$ Other personal & 4.2 & 4.0 & 5.1 & 3.2 & 2.5 & 2.2 & 3.0 \\
Determinants of retained earnings ${ }^{\mathrm{b}}$ & & & & & & & \\
Gross cash flow & 25.9 & 25.2 & 22.7 & 24.1 & 23.8 & 23.7 & 23.5 \\
Net cash flow & 17.4 & 16.9 & 13.5 & 13.7 & 12.2 & 12.5 & 12.2 \\
Taxes & 9.2 & 7.2 & 5.9 & 5.9 & 3.9 & 4.4 & 4.2 \\
Dividends & 3.8 & 3.6 & 2.6 & 2.4 & 2.9 & 3.1 & 3.5 \\
Interest (net) & -0.2 & 0.6 & 1.8 & 2.1 & 3.2 & 3.3 & 4.4 \\
Retained earnings & 4.6 & 5.5 & 3.2 & 3.3 & 2.2 & 1.7 & 0.1 \\
Addendum & & & & & & &
\end{tabular}

Source: National Income and Product Accounts, tables 1.14, 1.16, 5.1, 6.13, 8.8, and authors' calculations.

a. Private saving and its components are expressed as a percent of net national product.

b. The determinants of the retained earnings of domestic corporations are shown as a percent of gross corporate product.

c. The rate of return on nonfinancial corporate capital is the after-tax profits plus net interest payments as a percent of tangible capital.

ing those of state and local governments, became a major source of private saving after 1970, exceeding 3 percent of NNP for the period 1975-85. However, they are also part of the explanation for the decline in overall saving in the 1980s. By definition the annual accumulation in these funds equals the contributions to and the earnings of the funds less benefit payments. There has been almost no growth in the proportion of workers covered by pension plans since the mid-1960s, but there has been a greatly increased effort to fund the plans' future liabilities. ${ }^{4}$

The 1974 Employee Retirement Income Security Act (ERISA) increased the probability that workers would actually receive a benefit in future years, and it set a floor on funding for defined-benefit programs. Both of these factors led to higher employer contributions to the pension

4. See Pension and Welfare Benefits Administration (1989, p. 357). 
funds during the late 1970s. With the onset of high interest rates and the recovery of the stock market in the 1980s, however, many definedbenefit plans became overfunded under Internal Revenue Service (IRS) definitions, and many employers were unable to deduct further contributions when calculating their tax liability. The result was a sharp falloff in contributions to defined-benefit plans. The combination of employer contributions and the earnings of the private pension plans leveled off in the 1980s at around 4 percent of NNP. Meanwhile, benefit payments rose from 1.3 percent of NNP in 1980 to 3.3 percent in 1989, as more eligible workers reached retirement age. On balance, then, the net contribution of private pension programs to national saving has declined by about 1.5 percent of NNP since 1985. This downward trend will probably continue in future years because of recent actions by Congress to further restrict the funding of the programs. ${ }^{5}$

Meanwhile, state and local governments, unencumbered by federal regulation, have continued to build up their pension reserves, though saving from this source will also begin to dry up in the 1990s. Many of these funds are close to being fully funded and have matured to the point where they will begin to pay out substantial sums to new beneficiaries in the next decade. Thus, their contribution to national saving will also decline in the future.

The response of defined-benefit pension funds to higher market returns may provide a partial explanation for the failure of a higher after-tax return to serve as a positive incentive to private saving. As pointed out by Douglas Bernheim and John Shoven, defined-benefit plans are an extreme example of a target saver who reduces his or her saving in response to a higher return on existing wealth. ${ }^{6}$

5. A little noticed feature of the Omnibus Budget Reconciliation Act of 1987 significantly revised and tightened the criteria defining an overfunded defined-benefit pension plan. This revision effectively restricts the amount of tax-deductible contributions that can be made to a higher percentage of defined-benefit plans. The likely result will be a further reduction in the reserve accumulation of defined-benefit plans.

6. Bernheim and Shoven (1988). The data reported in table 2 understate the amount of pension saving, and consequently overstate other personal saving, because they ignore the growth in employee contributions-particularly to defined-contribution plans. In an earlier paper we found that the addition of employee contributions to such plans together with contributions to Individual Retirement Accounts and Keogh plans implied that nonretirement saving of households approached zero by 1987 . See Bosworth and Burtless (1990). 
The decline in the second type of personal saving, discretionary saving, is the focus of the remainder of this paper. This saving, undertaken directly by households, has declined from a peak of 5.1 percent of NNP in the early 1970s to a low of 2.2 percent observed over the last half of the 1980s. The trough was reached in 1987 , and a partial recovery has occurred over the last three years. Thus, the decline in discretionary saving is less a phenomenon of the 1980s than is implied by the overall total.

\section{Microeconomic Survey Measures of Saving}

Microeconomic surveys offer an alternative to the national income accounts in assessing trends in the consumption patterns and saving behavior of U.S. households. In this paper we consider two household surveys that provide contrasting conceptual measures of family saving. The Consumer Expenditure Survey (CES) collects detailed information about family consumption and income over the course of a year. From these data, family saving can be calculated as the difference between the flows of income and consumption spending. In contrast, the Survey of Consumer Finances (SCF) obtains a detailed inventory of family wealth holdings. By comparing a family's wealth position at two points in time, we can calculate the family's net saving over the period. ${ }^{7}$

Before considering the results from these kinds of tabulations, it is important to determine whether the decline in personal saving, so pronounced in the national accounts, will be picked up in a continuous household survey. Since the national accounts and household surveys measure saving in different ways, it is not obvious that lower saving in the national accounts would be reflected in a household survey. It is also useful to consider, at least briefly, the design and quality of the major household surveys.

\section{Comparing Survey Saving with NIA Saving}

The definitions of income, consumption, and saving used in the national income accounts differ in several important respects from those

7. For descriptions of the CES, see Pearl (1978) and Bureau of Labor Statistics (1989). For descriptions of the SCF, see Projector and Weiss (1966), Projector (1968), and Avery and others (1984). 
used in most surveys of individual households. It is possible, however, to adjust the NIA measures in a way that brings them closer to the concepts embodied in the main household surveys. After these adjustments are made, it is straightforward to recalculate NIA saving rates for the past few decades in order to determine whether NIA saving using "survey concepts" follows the path of saving reported in the national accounts.

Four major adjustments must be made to NIA data to bring them closer to the saving recorded by household surveys. These adjustments, which involve the NIA treatment of homeownership, employer pension contributions, net self-employment income, and third-party payments for household consumption, are discussed in the appendix. (Table A1 in the appendix provides a complete enumeration of the adjustments made to the 1989 national accounts needed to bring them in line with results from a household survey conducted the same year.) Our adjustments reduce both income and saving in the published national accounts by about 13 percent in $1989 .{ }^{8}$ Comparisons of the adjusted and official estimates of the personal saving rate for the period 1960-89 are shown in figure 1 . The significant feature of figure 1 is the marked reduction of personal saving after 1975, apparent in both the official and the adjusted series. The reduction began earlier in the adjusted than in the official series, but the magnitude of the decline is similar in both.

\section{Household Surveys}

The U.S. Bureau of Labor Statistics (BLS) has gathered information on family spending patterns and living costs since its first expenditure survey in 1888-91. The primary goal of the modern Consumer Expenditure Survey is to obtain information about typical household spending in order to derive expenditure weights for the consumer price index (CPI). In light of this goal, the greatest emphasis in the interview is placed on obtaining detailed and accurate information about family consumption. In addition, though, the survey obtains reasonably detailed information on money income and some rudimentary data on family

8. The proportional size of these adjustments has grown steadily over time. Because many of the adjustments affect income and consumption equally, however, they have far less impact on the saving rate. 
Figure 1. Alternative Measures of the Personal Saving Rate, 1960-89

Percent of disposable income

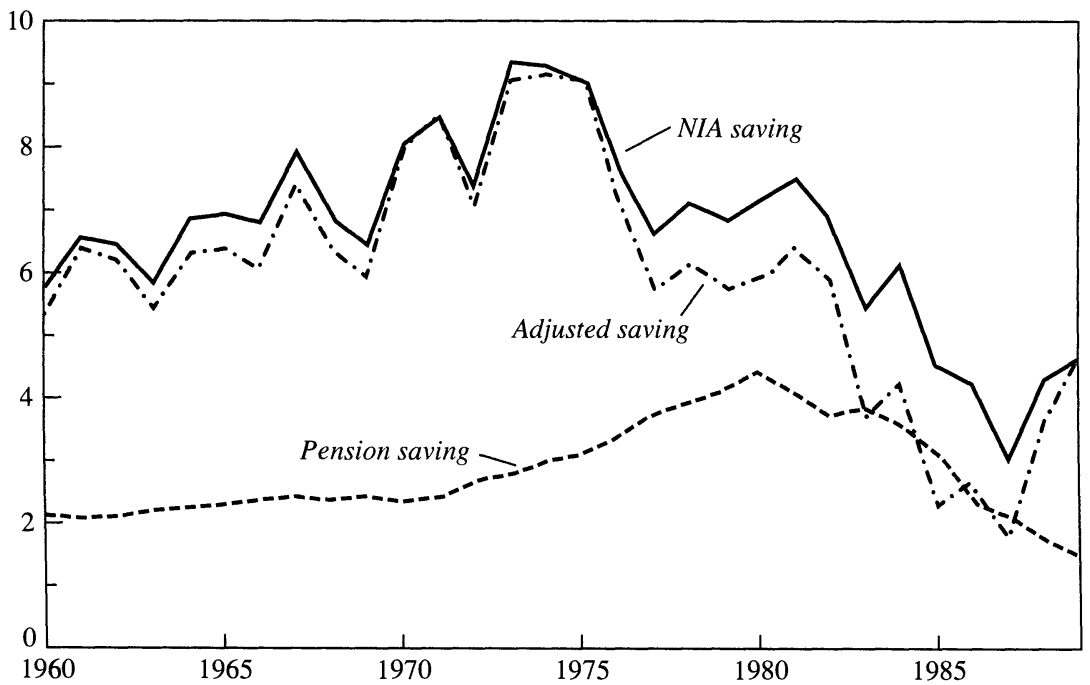

Sources: National Income and Product Accounts (NIA) and authors' adjustments of NIA data to convert them to cash accounting basis as described in the text and appendix.

wealth holdings. We derive our estimate of household saving in the CES by subtracting each household's reported consumption spending from its reported income.

Until 1980 the survey was conducted about once every ten years; since 1980 it has been conducted on a continuous basis. Our analysis of the CES is based on data from the 1972-73 annual surveys and from surveys for the period 1982-85. An examination of the data collected in the 1986-89 surveys suggests that there was a noticeable decline in the quality of both the income and consumption information reported for that period, so we excluded these surveys, at least initially, from our analysis. In order to keep our sample strictly comparable over time, we also restricted the analysis to urban households, which comprise 83 percent of all households and account for a somewhat higher percentage of total consumption. This restriction has almost no effect on our conclusions. In addition, because the 1972-73 and 1982-85 surveys did not treat college students in a consistent way, we exclude all households headed by someone under the age of 25 . Again, this restriction has little effect on the analysis. 
As an alternative to the measure of saving obtainable from an expenditure survey, we have also derived family saving using a series of wealth surveys. While measuring the change in a family's wealth would seem to offer a more direct method of ascertaining saving than the one used in a household expenditure survey, wealth surveys are relatively rare and are usually regarded with great skepticism. Even though respondents' recall of consumer expenditures is thought to be poor, their determination of their own net wealth position is thought to be even worse. To calculate saving using a wealth survey, it is necessary to conduct two surveys, the first to establish baseline wealth and the second to measure its change. Even if the responses on both surveys provide unbiased and tolerably accurate measures of the level of wealth, even small errors in the level could be large relative to the change in wealth used to measure saving.

A meaningful measure of saving thus requires that the second interview occur after a sufficiently long interval, so that the true change in wealth is not swamped by reporting errors on the two surveys. Unfortunately, long delays between surveys can cause severe sample loss because of attrition or changes in household composition. A more subtle issue arises because wealth changes originate from essentially unpredictable capital gains and losses as well as from a consumer's conscious decision to save a part of current spendable income. We sought to measure household saving from the wealth survey exclusive of capital gains and losses. To accomplish this we estimated the capital gains each household would have enjoyed on its initial stock portfolio if the portfolio had risen in value at the rate of increase in the Standard and Poor's index. These imputed capital gains were then subtracted from the change in the household's wealth. Capital gains on owner-occupied homes can be obtained directly from the survey and were similarly excluded from our measure of saving. The appendix contains further details regarding our definition of saving.

We use two sets of wealth surveys to provide us with information on U.S. household saving. The first of these is the Survey of Financial Characteristics of Consumers, conducted in 1963, and the companion Survey of Changes in Family Finances, conducted a year later in $1964 .^{9}$ The second set of data is drawn from the 1983-86 Surveys of Consumer

9. See Projector and Weiss (1966) and Projector (1968). 
Finances. ${ }^{10}$ For simplicity, we refer to both sets of surveys as SCF. The 1986 survey was a reinterview of many households first interviewed in the 1983 Survey of Consumer Finances. Like the comparable survey in 1963 , the $1983 \mathrm{SCF}$ enrolled a sample that was specially drawn to represent high-income families adequately_such families account for a disproportionate fraction of the nation's private wealth. Evaluations of the 1963 and 1983 data suggest that the designers of the survey were quite successful in obtaining reliable wealth data. ${ }^{11}$

\section{Accuracy of the Survey Data}

Before analyzing the saving behavior reflected in household survey data, one must consider the quality of the data recorded by interviewers. In the appendix we show a variety of tabulations that compare income and consumption from the CES with similar data from other sources. The Census Bureau, BLS, and the Federal Reserve have performed additional tabulations comparing the CES and SCF information and similar data reported in the national income accounts and the Flow of Funds. On the whole, the wealth data on the SCF appear to have received better marks for accuracy. Reports issued by the Federal Reserve indicate that the family asset and debt totals obtained in the SCF correspond closely to aggregates reported in the Flow of Funds figures, and we find that the income data compare reasonably well with income reported in other sources.

The U.S. expenditure surveys are more problematical. Not only do these surveys record slightly less money income than the amount reported on the Census Bureau's Current Population Survey (CPS), they understate by an even larger amount household consumption spending.

10. See Avery and others (1984).

11. See Avery, Elliehausen, and Kennickell (1988) and the citations they mention for further details. The 1983 survey appears to have obtained data that match the wealth tabulations from the Flow of Funds, implying that some of the difficulties of other wealth surveys result from underrepresentation of households with extremely high wealth holdings. (See the appendix for further detail.) A second, more detailed follow-up interview was conducted in 1989, but data from that interview will not become available until late 1991. Two other wealth surveys also became available during the 1980s. The 1984 and 1989 interviews of the Panel Survey on Income Dynamics included questions on wealth holdings. The Survey of Income and Program Participation also included questions about family assets. Unfortunately, there is no counterpart to these surveys for an earlier decade when household saving rates were higher. 
Since saving is the difference between income and consumption, it will be overstated in the CES. If the overstatement of saving remained constant through time, the CES would still provide reliable data for studying the change in saving. Unfortunately, the income data from the CES have deteriorated somewhat faster than the consumption data, leading to a spurious fall in the measured saving rate.

We examine this underreporting problem with some care in the appendix. Our analysis suggests that the differential trend in the underreporting of income and consumption may yield a moderate overstatement of the decline in aggregate saving. Perhaps one-third of the apparent drop in the saving rate between $1972-73$ and 1983-84 is due to the trend in misreporting. The remainder, however, is due to a genuine fall in saving. This conclusion is reinforced by our analysis of the asset changes reported by households in the CES, which also shows a decline in saving between 1972-73 and 1982-85. The CES estimates of saving shown in the next section are based on unadjusted differences between individual household income and household consumption spending. Even without adjustments for differential underreporting of income and consumption spending, the expenditure surveys appear to provide a useful and tolerably accurate source of information for analyzing the decline in household saving.

\section{Explaining the Decline in U.S. Saving}

Survey data obtained from individual households are particularly useful for evaluating the differential saving behavior of identifiable subgroups in the population and for exploring the influence of compositional changes in the population. A number of hypotheses have been advanced that attribute the decline in the saving rate to reduced saving on the part of specific groups, such as members of the baby-boom generation or those households that enjoyed large capital gains on realestate or financial assets. Other explanations have emphasized the growth in the fraction of households headed by the elderly or by single mothers, who traditionally have had low saving rates.

The microeconomic survey data have impressed us with the extreme variability in the saving rates reported by individual households. This variability probably reflects both the true variability in individual eco- 
nomic circumstances and serious reporting errors. The magnitude of the variance leads us to be skeptical that analysis of the data at the individual household level can yield reliable conclusions. We do believe, however, that the variability can be reduced by focusing on average saving rates of specific socioeconomic groups. ${ }^{12}$ The characteristics we have used to group households include age, household composition, income, and asset ownership. Our study does not, however, focus on the actual level of the saving rate obtained from the surveys; instead it emphasizes the change in the saving rates of specific groups over time. We present comparable data from both the Consumer Expenditure Survey and the Survey of Consumer Finances. As explained in the previous section, each of these surveys has its own advantages and disadvantages for measuring saving at the level of the individual household. The use of both surveys is an important check on any conclusions that emerge.

\section{Demographic Change}

Change in the age structure of the population has received much attention in recent years, both as an explanation for the past decline in saving and as a potential source of sharply lower future saving in the industrial world. According to the standard life-cycle view, heads of household accumulate wealth by saving during most of their working years and then dissaving in retirement. To the extent that life-cycle motives dominate saving behavior, increases in the proportion of income received by very young or retired heads of household should reduce the aggregate saving rate. Along somewhat different lines, it has also been argued that the decline in saving over the last decade can be traced to the changing behavior of specific groups in the population. Michael Boskin and Lawrence Lau, for example, attribute the decline to the saving behavior of those born after $1939 .{ }^{13}$ Other analysts have focused on the effects of demographic change on the investment side of the saving and investment balance. They have argued that expectations of

12. Our analysis of the data suggests that samples with 200-300 observations in each category are required to obtain meaningful differences in cell means for the Survey of Consumer Finances. Cell sizes on the order of 500-1000 are needed for the Consumer Expenditure Survey. The variance of saving in the CES is substantially larger than in the SCF.

13. Boskin and Lau (1988a, 1988b). 
slower future growth in the labor force will reduce the demand for capital and thus the need for current saving. ${ }^{14}$

MACROECONOMIC EVIDENCE. To date, there have been only a few tests of demographic influences on the trend in private saving. Nearly all have been based on an analysis of aggregate data. One approach has been to construct an index of the influence of demographic effects on the aggregate private saving rate. This can be accomplished using a simple two-step procedure. First the saving rate of each age group must be determined for some base period. Then the fraction of aggregate income received by households in each age group is calculated for past or future periods. The index of demographic influence is the weighted sum of saving rates in each age group, with the weights equal to the proportion of aggregate income received by each group..$^{15}$

It is assumed in such an exercise that the income share of each age group is known or can be predicted and that the relative saving propensity within each age category remains unchanged over time. Under the additional assumption that the relative incomes of each age group remain constant over time, a simpler measure of demographic influence is the dependency ratio - the ratio of the population of very old and very young people to the population of working-age adults (say, people aged 20-64).

A second approach has been to include age composition as an explanatory variable in regressions that predict aggregate time-series consumption or saving behavior. Studies using this approach implicitly assume that the age profile of saving and relative income is constant over time. For example, in an attempt to establish the influence of population aging on aggregate saving, economists at the International Monetary Fund (IMF) recently analyzed the consumption behavior of the seven largest economies in the Organization for Economic Cooperation and

14. Cutler and others (1990) and Masson and Tyron (1990). Such an argument may have limited relevance in today's relatively open international economy, in which capital moves easily across national boundaries. It also ignores the intergenerational issues that arise from large changes in the proportion of the population that is retired and the need to provide for their consumption out of current production.

15. See Aaron, Bosworth, and Burtless (1989, pp. 137-40). Auerbach and Kotlikoff (1989) produced a more refined index that incorporates government as well as private consumption. Both studies conclude that demographic changes should raise private saving in the 1990s and reduce it early in the next century. But the studies also show that demographic indexes bear little or no relation to past saving trends. 
Development (OECD) over the period 1967-87. They found a significant statistical correlation between private saving rates and the change in the proportion of people under 15 and over 65 years of age. ${ }^{16}$

A similar correlation has been found by Charles Horioka in the aggregate data for Japan. His results led him to forecast that the rapid aging of the Japanese population will yield a private saving rate below that of the United States by the year 2005. ${ }^{17}$ The main difficulty with these aggregative approaches is that the age structure of the population changes so slowly that any index resembles a simple trend, which could be easily confused with the influence of other secular changes in the determinants of saving.

The strongest empirical evidence for the importance of demographic factors has been obtained through a series of cross-sectional studies comparing international differences in saving rates. ${ }^{18}$ Some of these studies were undertaken as part of the debate over the effects of social security on saving and included measures of the age distribution of the population in the regressions. For data from the late 1960s and early 1970 s, the studies generally found a significant negative correlation between the proportion of a nation's population that was very young or retired (that is, dependent) and that nation's saving rate. The analysts obtained the plausible result that the negative influence of the proportion of aged or retired people on private saving was about twice that of children. As an offset to the rise in the dependency rate, which reduces overall saving, the studies also found that an increased propensity to earlier retirement tends to raise the saving rate of the currently employed.

Bosworth recently attempted to replicate the main findings of the cross-sectional studies. ${ }^{19} \mathrm{He}$ found that the earlier results are highly sensitive to the specific countries included in the analysis. Results are also affected by the data revisions that have occurred since the original studies were done. Bosworth concluded that the influence of demographic factors on aggregate saving is smaller and less reliably determined

16. Masson and Tyron (1990). The regression was based on pooled data from the individual countries, and the statistical significance of the demographic variable was limited to the 1980 s.

17. Horioka (1989b).

18. See, for example, Modigliani (1970), Feldstein (1980), Modigliani and Sterling (1983), and Horioka (1989a).

19. Bosworth (1990). 
than the effects estimated in the earlier analyses. Nonetheless, demographic factors continued to be correlated with the observed differences in national saving rates in the early $1980 \mathrm{~s}$.

The limitations of the international cross-sectional findings are apparent when they are used to predict the trend of aggregate saving within individual countries. According to the results obtained in the typical cross-sectional regression, the net effect of age composition changes should have been to increase private saving in most industrialized countries through the late 1970 s and early $1980 \mathrm{~s} .{ }^{20}$ Private saving should have increased because the large decline in the proportion of the population that was young dominated the increase in the proportion that was retired. In addition, the increased propensity toward early retirement in the industrial countries should have increased the planned saving of the current working population. Despite these predictions, however, private saving rates fell everywhere except the United Kingdom and Canada. The low predictive power of the cross-sectional studies suggests that they have limited value in explaining the impact of demographic factors on recent trends in saving.

HOUSEHOLD SURVEY EVIDENCE. Microeconomic survey data provide an alternative source of information about the possible influence of demographic change on national saving rates. Saving profiles based on age and estimated using microeconomic data indicate why the previous studies, which assume constant age-based saving profiles, fail to explain the movement in aggregate saving. In table 3 we show saving rates by age of household head compiled using the two U.S. household surveys. The top half of the table displays saving rates, population shares, and relative incomes for five age groups calculated using the 1963 and 198386 SCF. The same measures, computed using the 1972-73 and 1982-85 CES, are shown in the bottom half of the table. As noted earlier, we attempted to make the two measures of saving comparable by removing capital gains on initial holdings from the wealth changes calculated in the SCF.

Both surveys capture the decline in the personal saving rate during the 1980s that is evident in the national accounts. While the two surveys differ in the reported level of saving rates across age groups, the size of the decline in the total saving rate is surprisingly similar -4.5 percentage points in the SCF and 4.3 points in the CES. 
Table 3. Household Survey Results for Age Distribution of Saving and Income, United States, 1963-85

Percent

\begin{tabular}{|c|c|c|c|c|c|c|}
\hline \multirow[b]{2}{*}{ Item } & \multicolumn{5}{|c|}{ Age group } & \multirow{2}{*}{$\begin{array}{c}\text { Survey } \\
\text { total }\end{array}$} \\
\hline & $25-34$ & $35-44$ & $45-54$ & $55-64$ & 65 and over & \\
\hline & \multicolumn{6}{|c|}{ Survey of Consumer Finances } \\
\hline \multicolumn{7}{|l|}{ Saving rate } \\
\hline 1963 & 14.7 & 11.3 & 17.2 & 14.2 & 11.2 & 14.0 \\
\hline $1983-85$ & 13.6 & 10.1 & 10.3 & 10.6 & 2.5 & 9.5 \\
\hline Change & -1.1 & -1.2 & -6.9 & -3.6 & -8.7 & -4.5 \\
\hline \multicolumn{7}{|c|}{ Age distribution } \\
\hline 1963 & 21.5 & 20.7 & 20.8 & 17.0 & 19.9 & 100.0 \\
\hline $1983-85$ & 20.5 & 18.4 & 18.3 & 15.4 & 27.4 & 100.0 \\
\hline \multicolumn{7}{|c|}{ Relative income $\mathrm{a}^{\mathrm{a}}$} \\
\hline 1963 & 104.0 & 125.5 & 124.5 & 91.8 & 50.6 & 100.0 \\
\hline \multirow[t]{2}{*}{$1983-85$} & 90.5 & 130.8 & 129.5 & 100.4 & 66.6 & 100.0 \\
\hline & \multicolumn{6}{|c|}{ Consumer Expenditure Survey } \\
\hline \multicolumn{7}{|l|}{ Saving rate } \\
\hline $1972-73$ & 9.5 & 12.1 & 16.8 & 22.9 & 14.9 & 15.1 \\
\hline $1982-85$ & 9.6 & 8.6 & 10.5 & 15.8 & 11.5 & 10.8 \\
\hline Change & 0.1 & -3.5 & -6.3 & -7.1 & -3.4 & -4.3 \\
\hline \multicolumn{7}{|c|}{ Age distribution } \\
\hline $1972-73$ & 22.6 & 18.7 & 20.2 & 17.5 & 21.0 & 100.0 \\
\hline $1982-85$ & 25.8 & 21.1 & 15.5 & 16.0 & 21.6 & 100.0 \\
\hline \multicolumn{7}{|c|}{ Relative income ${ }^{a}$} \\
\hline $1972-73$ & 95.0 & 119.9 & 126.5 & 104.9 & 58.0 & 100.0 \\
\hline $1982-85$ & 94.1 & 120.3 & 124.5 & 102.7 & 67.5 & 100.0 \\
\hline
\end{tabular}

Source: Authors' calculations using data from the Survey of Consumer Finances and the Consumer Expenditure Survey. We attempted to make the two measures of saving comparable by removing capital gains on initial holdings from wealth changes calculated in the Survey of Consumer Finances. The saving rate shown for the Survey of Consumer Finances is savings as a percent of income, and the saving rate shown for the Consumer Expenditure Survey is saving as a percent of disposable income.

a. The average income of each group relative to average income for the entire survey is shown for the Survey of Consumer Finances. The relative disposable income for each group is shown for the Consumer Expenditure Survey.

The most interesting aspect of the survey data is the decline in saving for almost all age groups. There is no evidence that the decline is concentrated among households headed by members of the baby-boom generation, as suggested by Boskin and Lau. ${ }^{21}$ In fact, both surveys indicate that the relative decline in saving has been smaller among younger households. In the SCF, saving rates fell only about 1 percentage point for the two groups aged 25 to 44 between 1963 and 1983-85. In the CES, the saving rate of households headed by someone under the age of 45 fell an average of just 1.7 percentage points between 1972-73 and

21. Boskin and Lau (1988a, 1988b). 
$1982-85$. By contrast, the saving rate of households headed by someone over 45 fell 7 percentage points in the SCF and 6 percentage points in the CES. For both surveys, then, the drop in saving among younger households was significantly smaller than among older households.

The saving rates shown in table 3 are reported without standard errors. We believe that the standard errors may provide a misleading measure of the statistical significance of differences in saving rates over time, because of the reporting errors discussed earlier. Reporting errors can bias the measured change in saving rates, thus making the estimate of standard error unreliable. In addition, it is not possible to compute standard errors directly because the saving rate in each subgroup represents the ratio of total saving to total income in the group; it is not the average of the individual saving rates in the group. We have, however, estimated standard errors using the bootstrap method. ${ }^{22}$ (The bootstrap estimates of the standard errors are reported in the appendix.) The standard error of the difference in saving rates in the SCF is about 1.5 percentage points for the overall sample. In the much larger CES the standard error of the overall difference is just 0.7 percentage points. For smaller subgroups in each survey the standard errors can be several times larger. Thus, saving rate changes of less than 2 percentage points probably have little statistical significance.

The trend in real interest rates over the period provides a possible explanation for the age pattern of the saving decline. The real corporate bond rate averaged 2.6 percent in 1963 and 3.3 percent in the 1972-73 period but then jumped to 7.5 percent between 1982 and $1985 . .^{23}$ Although the usual expectation is that a rise in the real rate of return will generate additional personal saving, economic theory is in fact ambiguous on this point. Among older households a jump in the rate of return on existing wealth holdings may actually reduce saving out of current income, because older consumers find that their existing wealth permits a higherthan-anticipated flow of consumption in retirement. Younger consumers have less wealth holdings, however. Their saving is more affected by

22. For a clear introduction to the technique, see Efron and Tibshirani (1986). In our application of the method, we drew 50 random samples from each subgroup, with replacement, and calculated the standard error of the resulting distribution of 50 estimates of the subgroup saving rate.

23. Our measure of the real corporate bond rate is the difference between Moody's estimate of the BAA corporate bond yield and consumers' expectations of the annual inflation rate as reported in the University of Michigan's survey of price expectations. 
the fact that the jump in the real rate of return makes current consumption more costly relative to future consumption. Hence, their rate of saving could rise, or at least decline by less than the saving of older consumers.

Except for the 1983-86 SCF, the results show a "humped" pattern to the age distribution of saving rates. ${ }^{24}$ But, as noted in other studies, the saving rate of elderly households remains positive. As a result, there is not a large enough difference in saving rates by age for the graying of the U.S. population to have had an appreciable effect on the overall saving rate.

The aggregate saving rate in each survey is expressed as

$$
S_{t}=\sum_{i=1}^{G} w_{i t} y_{i t} s_{i t}
$$

where

$S_{t}=$ aggregate saving rate in period $t$

$w_{i t}=$ proportion of household heads in the $i$ th age group;

$y_{i t}=$ ratio of average income in the $i$ th group to the overall average;

$s_{i t}=$ saving rate of the $i$ th age group; and

$G=$ number of age groups.

Given information on $w, y$, and $s$, from two surveys widely spaced over time, changes in the overall saving rate can be decomposed into changes in saving rates within age categories, changes in the age distribution of those households, and changes in relative incomes.

The trivial significance of demographic factors on saving trends can be demonstrated using equation 1 . The table below shows the effect of these factors on three saving rates (in percent). The first column shows the population saving rate actually recorded on the surveys. The second column shows the saving rates that would have been recorded in the later surveys if the age distribution of different age groups had remained fixed at the distribution observed by the first survey (that is, if $w_{i t}=w_{i 1}$ ). Only the saving rates within each age group and the relative incomes of the different age groups are allowed to vary over time. In the third column, the age distribution and the relative incomes of different age groups are held fixed at the levels observed by the first survey (that is,

24. The saving rate of the elderly would be reduced further if pension benefits were excluded from the current income of the retired. 
$w_{i t}=w_{i 1}$ and $\left.y_{i t}=y_{i 1}\right)$. Only the saving rates within age groups are allowed to vary.

$\begin{array}{cccc}\text { Survey } & \text { Saving rate } & \begin{array}{c}\text { With age and } \\ \text { Welative } \\ \text { Weld constant }\end{array} & \begin{array}{c}\text { income held } \\ \text { constant }\end{array} \\ \begin{array}{c}\text { SCF } \\ 1963\end{array} & 14.0 & 14.0 & 14.0 \\ 1983-85 & 9.5 & 10.3 & 10.2 \\ C E S & & & \\ 1972-73 & 15.1 & 15.1 & 15.1 \\ 1982-85 & 10.8 & 11.1 & 11.0\end{array}$

The results in the table demonstrate convincingly that aggregate saving fell because saving dropped off within age groups. Of the total drop in saving in the SCF, 84 percent (or 3.8 percentage points) is due to the fall in within-group saving rates. For the CES, 95 percent (or 4.1 percentage points) is attributable to the drop in within-group saving rates. Changes in the age distribution of households and in the relative incomes of households in different age categories contributed only slightly to the decline.

ALTERNATIVE TREATMENT OF PENSIONS. The previous analysis does understate the contribution of demographic change because it excludes saving within employer pension plans. On a national accounts basis, part of the decline in personal saving during the 1980s was attributable to reduced saving within these pension plans. The surveys provide data on pension benefit payments, but we lack reliable information on employer contributions and the capital income of the plans. Private employer contributions to pension plans represent about 4 percent of the money wages paid to private wage and salary workers. Interest earnings of the funds have risen over time and by the early 1980s exceeded employer contributions to the plans. If pension contributions and interest earnings were included in workers' incomes, the effect on household saving would be nontrivial.

We can roughly assess the significance of pension contributions for our saving estimates by imputing pension contributions and interest earnings for wage earners in the survey. These estimates of pension compensation can then be added to the income reported on the surveys 
to obtain an alternative measure of workers' incomes. ${ }^{25}$ To reflect the NIA treatment of pension payments in our calculations, we also modified our definition of household income to exclude the pension benefits (though not the social security benefits) reported on the surveys. This is clearly an extreme assumption for two reasons. First, pensioners such as federal annuitants and retired servicemen receive pension payments that amount to transfers rather than dissaving from a pension reserve. And second, many pensioners' incomes should be adjusted to include at least part of the interest income earned on pension reserves. Instead, in our modified definition all of the interest income is credited to current workers.

The table below shows the effect of these modifications in the treatment of pension contributions and pension benefits on saving rates (in percent).

\begin{tabular}{crrrr} 
Income & \multicolumn{5}{c}{ Saving rate by age group (CES) } \\
\cline { 2 - 5 } definition & $25-44$ & $45-64$ & Over 64 & Total \\
Original & & & & \\
1972-73 & 10.8 & 19.4 & 14.9 & 15.1 \\
1982-85 & 9.1 & 13.0 & 11.5 & 10.8 \\
Change & -1.7 & -6.4 & -3.4 & -4.3 \\
Modified & & & & \\
1972-73 & 15.5 & 21.9 & 1.8 & 16.9 \\
1982-85 & 17.2 & 15.2 & -3.9 & 14.0 \\
Change & 1.7 & -6.5 & -5.7 & -2.9
\end{tabular}

The modifications raise the measured income and saving rates of wage and salary workers and reduce the income and saving rates of pensioners. This is reflected in the table in the higher saving rates of the young and dramatically reduced saving rates of the elderly. Even with these modifications, aggregate private saving fell between the two survey

25. The sum of employer contributions and interest earnings in pension plans amounted to 5.3 percent of private wage and salary earnings in 1972-73 and 8.9 percent of private money wages in 1982-84. In our imputation of pension compensation to wage and salary workers, we assumed that these percentages could be applied to earnings reported by all employees, including both private and public employees. In fact, contributions for state and local employees are likely to exceed this percentage, since government employees are covered by more generous pensions than private employees. On the other hand, contributions for federal workers should probably be excluded from private saving since it is doubtful that such contributions result in a genuine pension reserve. 
dates, with the decline concentrated among those aged 45 or older. The modified definition of saving actually shows a small increase in saving among younger households, although this is probably an artifact of our imputation procedure. ${ }^{26}$

Because saving rates differ so widely by age, it is possible that the modified definition of saving implies a larger response of aggregate saving to shifts in the age structure of the population. It turns out, however, that virtually all of the drop in the modified measure of saving between the two survey periods- 2.8 percentage points out of the 2.9 percentagepoint drop-is still due to the drop in saving within age groups. Moreover, when we forecast the future course of the aggregate saving rate using population projections from the Social Security Administration, we find only a small impact of demographic shifts. Using age-specific saving rates obtained under the modified definition, the aggregate saving rate is projected to rise slightly over the remainder of the century and then fall about 1 percentage point between 2000 and 2020 .

In sum, even under a definition of household saving that exaggerates the extent of private saving among young householders and understates saving among the elderly, we find that changes in the age structure of the population have had and will continue to have only a modest effect on the overall saving rate. Virtually all of the recent fluctuation in saving has occurred because middle-aged and older consumers have sharply reduced their saving. The household survey data thus provide little support for the claim that the saving rate will climb sharply in the near future as the baby-boom generation moves into age groups with historically high saving rates, nor is there good evidence that saving will inevitably decline in the future as the relative size of the retired population climbs.

HOUSEHOLD COMPOSITION. Saving rates may differ across families not only because of the age of the family head, but also because of differences in household composition. Heads of U.S. families have experienced major changes in marital status and child-rearing responsibilities over the last two decades. The cost of providing for a spouse and

26. The cost of funding pensions is much lower for younger than for older workers. Younger workers are less likely to be covered by a plan, and, if covered by a definedbenefit plan, the required employer contributions are likely to be smaller. Our imputation procedure nonetheless assumes that the contribution rate is identical for all wage and salary workers, irrespective of age. 
Table 4. Saving and Income, by Family Type, United States, 1963-85 $^{\mathrm{a}}$

Percent

\begin{tabular}{|c|c|c|c|c|c|}
\hline \multirow[b]{2}{*}{ Item } & \multicolumn{2}{|c|}{ Married } & \multicolumn{2}{|c|}{ Single } & \multirow[b]{2}{*}{$\begin{array}{c}\text { Survey } \\
\text { total }\end{array}$} \\
\hline & $\begin{array}{c}\text { With } \\
\text { children }\end{array}$ & $\begin{array}{l}\text { Without } \\
\text { children }\end{array}$ & $\begin{array}{c}\text { With } \\
\text { children }\end{array}$ & $\begin{array}{l}\text { Without } \\
\text { children }\end{array}$ & \\
\hline & \multicolumn{5}{|c|}{ Survey of Consumer Finances } \\
\hline \multicolumn{6}{|l|}{ Saving rate } \\
\hline 1963 & 14.5 & 15.9 & -0.4 & 15.5 & 14.4 \\
\hline $1983-85$ & 9.4 & 15.4 & 1.2 & 11.9 & 11.0 \\
\hline Change & -5.1 & -0.5 & 1.6 & -3.6 & -3.4 \\
\hline \multicolumn{6}{|c|}{ Population distribution } \\
\hline 1963 & 54.2 & 21.0 & 6.9 & 17.9 & 100.0 \\
\hline $1983-85$ & 40.1 & 23.2 & 10.5 & 26.2 & 100.0 \\
\hline \multicolumn{6}{|c|}{ Relative income } \\
\hline 1963 & 113.1 & 115.3 & 56.5 & 59.1 & 100.0 \\
\hline \multirow[t]{2}{*}{$1983-85$} & 115.8 & 124.6 & 62.8 & 68.8 & 100.0 \\
\hline & \multicolumn{5}{|c|}{ Consumer Expenditure Survey } \\
\hline \multicolumn{6}{|l|}{ Saving rate } \\
\hline $1972-73$ & 14.1 & 22.3 & -14.3 & 12.0 & 15.1 \\
\hline $1982-85$ & 7.5 & 18.2 & -11.1 & 14.2 & 10.7 \\
\hline Change & -6.6 & -4.1 & 3.2 & 2.2 & -4.4 \\
\hline \multicolumn{6}{|c|}{ Population distribution } \\
\hline 1972-73 & 48.6 & 25.3 & 7.3 & 18.9 & 100.0 \\
\hline 1982-85 & 39.5 & 24.4 & 10.2 & 26.0 & 100.0 \\
\hline \multicolumn{6}{|c|}{ Relative income } \\
\hline 1972-73 & 116.6 & 112.5 & 53.4 & 58.6 & 100.0 \\
\hline $1982-85$ & 118.5 & 117.6 & 58.8 & 71.4 & 100.0 \\
\hline
\end{tabular}

Source: Authors' calculations using data from the Survey of Consumer Finances and the Consumer Expenditure Survey. See the text and notes to table 3 for further detail.

a. The table shows the saving behavior of households in which the head of the household is aged 25 to 64 . The survey total does not correspond to totals in other tables because of the different sample size.

children may have a sizable effect on saving decisions. Married couples may behave differently than single people because of the income insurance provided by a second potential earner, and the increased prevalence of single-headed households with children may have reduced the overall saving rate.

Table 4 displays information about the saving of different types of households. The saving rates reported in the table show that saving varies widely by marital status and the presence or absence of dependent children. The decomposition of saving shown in the table fails to provide a simple explanation for the drop in aggregate saving, however. Both the SCF and CES imply that single heads of household with children 
have the lowest saving rates in the population. Moreover, a significant shift toward this type of family structure has occurred since the $1960 \mathrm{~s}^{27}$ But the incomes of single-parent families are simply too low for their increased prevalence to have had a noticeable effect on the overall saving rate. Virtually all of the decline in average household saving has occurred because of a plunge in the saving within the different family groups defined in table 4. Little of it occurred as a result of shifts in the relative income distribution or in the distribution of households across different family types. If we calculate the weighted sum of group saving rates for the 1980s using the population weights and relative incomes of the earlier survey period, the projected total saving rate is almost the same as the actual saving rate observed in the 1980s. In fact, the hypothetical rate, assuming $w_{i t}=w_{i 1}$ and $y_{i t}=y_{i 1}$, is within 0.2 percentage points of the observed rate for both the CES and SCF. All of the remaining decline in aggregate saving is due to the drop in saving within family groups.

As a further check on these results, we tabulated the saving rates of households headed by married couples aged 24-65 and differentiated between families according to household size and the number of earners present. Those tabulations, not reported here, show the same general pattern evident in tables 3 and 4 . Both the wealth and the expenditure surveys reveal, not surprisingly, that the family saving rate shrinks as household size rises but increases with the number of earners. From our perspective, however, the interesting result is that saving rates decline over time in all groups, regardless of family size or number of earners. In addition, despite large changes in the composition of families, with respect to both household size and number of earners, shifts in composition actually should have boosted the aggregate saving rate by 0.2 to 1.5 percentage points. Thus, the decline in total saving occurred despite shifts in family structure that should have raised it.

\section{Income Distribution}

Basic life-cycle consumption theory suggests that saving rates should not be closely linked to permanent income. Indeed, the rate of saving

27. The differences in saving rates between the two surveys' groups of single heads of household with children illustrate that the SCF was much better at obtaining information on government transfers and alimony payments than was the CES. 
Table 5. Saving and Income, by Income Quintile, United States, 1963-85

Percent

\begin{tabular}{|c|c|c|c|c|c|c|}
\hline \multirow[b]{2}{*}{ Item } & \multicolumn{5}{|c|}{ Income quintile } & \multirow{2}{*}{$\begin{array}{c}\text { Survey } \\
\text { total }\end{array}$} \\
\hline & First & Second & Third & Fourth & Fifth & \\
\hline & \multicolumn{6}{|c|}{ Survey of Consumer Finances } \\
\hline \multicolumn{7}{|l|}{ Saving rate } \\
\hline 1963 & -0.3 & 7.9 & 15.4 & 13.5 & 16.5 & 14.0 \\
\hline $1983-85$ & -2.4 & -2.9 & 10.0 & 9.9 & 12.5 & 9.5 \\
\hline Change & -2.1 & -10.8 & -5.4 & -3.6 & -4.0 & -4.5 \\
\hline \multicolumn{7}{|c|}{ Relative income } \\
\hline 1963 & 19.4 & 50.7 & 85.5 & 123.9 & 220.4 & 100.0 \\
\hline \multirow[t]{2}{*}{$1983-85$} & 20.6 & 46.2 & 77.7 & 119.8 & 232.7 & 100.0 \\
\hline & \multicolumn{6}{|c|}{ Consumer Expenditure Survey } \\
\hline \multicolumn{7}{|l|}{ Saving rate } \\
\hline $1972-73$ & -45.4 & -1.5 & 9.0 & 17.5 & 28.6 & 15.1 \\
\hline $1982-85$ & -92.1 & -10.3 & 8.7 & 16.7 & 25.8 & 10.8 \\
\hline Change & -46.7 & -8.8 & -0.3 & -0.8 & -2.8 & -4.3 \\
\hline \multicolumn{7}{|c|}{ Relative income } \\
\hline $1972-73$ & 24.8 & 58.1 & 89.9 & 124.6 & 206.8 & 100.0 \\
\hline $1982-85$ & 24.2 & 55.9 & 86.8 & 124.3 & 208.9 & 100.0 \\
\hline
\end{tabular}

Source: Authors' calculations using data from the Survey of Consumer Finances and the Consumer Expenditure Survey. See the text and notes to table 3 for further detail.

should be independent of the level of lifetime income. (Noted exceptions to the basic model are that consumers may be constrained in liquidity or subject to a volatile income stream, which gives rise to the positive correlation between saving rates and income levels observed in microeconomic data.) More specifically, theory suggests that estimates of saving rates arranged by income class should be highly misleading. Transitory movements in income will lead to a pronounced overstatement of normal saving by households reported to be in the upper part of the income distribution in a given year and an understatement of normal saving by those near the bottom. However, if we assume that transitory income movements are of roughly equal relative importance in all years, it may still be useful to examine the changes in saving over time at different points in the income distribution.

Saving rates arranged by quintiles of the income distribution are reported in table 5. Again, the most striking feature of the table is the uniformity of the decline in saving across groups. The SCF shows a marked decline in the saving rates of every income group over the period 1963-85. And, except for the middle quintile, the saving rate also falls substantially in the CES. 
Relative income shares by income class are similar in the SCF and CES, but the SCF reports a larger proportion of total income in the highest quintile, presumably because a special effort was made to survey the very wealthiest households, which may be underrepresented in the CES. Saving rates in the CES, however, are more variable by income class. The very low average saving rates in the poorest CES households can be attributed to the survey's failure to measure transfers and alimony accurately. These income sources are more common among poorer households. This problem is exacerbated by the fact that the consumption of poor families is probably more accurately measured than that of wealthier households. The underestimate of income is less important for the SCF since it has no impact on the measurement of saving and thus produces only a minor overstatement of the saving rate. Both surveys show little change in the relative income distribution over time, with the notable exception that the relative income of the richest quintile in the SCF rose. On balance, shifts in the distribution of income should have slightly increased saving in the 1980s compared to earlier decades.

\section{Capital Gains}

Some analysts, citing the extraordinary rise in equity values since 1982 , believe that increases in the wealth-income ratio provide a simple explanation for the decline in saving rates. Such an argument is particularly relevant given the prominent role of the wealth-income ratio in the life-cycle model of consumer behavior. Adherents of this view, however, appear to forget the collapse of equity prices in the 1973-74 period and in 1982. In fact, since the early 1970s households have experienced little or no real gain on equities and may even have experienced real losses depending on the precise starting and ending dates used for measurement. ${ }^{28}$ Total household wealth fell about 10 percent in real terms as a result of the 1973-74 stock market decline. A partial recovery of the market and significant real gains on home real estate in the late 1970s restored some of those losses. But there were again large losses on equities in the early 1980 s, and real-estate price increases in that period failed to keep up with general inflation. Households experienced substantial capital gains in equities and housing in the

28. Bosworth and Burtless (1990). 
mid-1980s, but these occurred after a large part of the decline in saving rates.

We examine the effects of capital gains by contrasting the behavior of households with and without large asset holdings. In particular, we compare families owning stocks and bonds with families that own no corporate equity or debt. We also compare saving among homeowners with that among nonhomeowners.

The SCF and CES report nearly identical estimates of the percentage of households owning bonds or owning equities ( 29 percent versus 26 percent), even though the identification of wealth holding is only a minor objective of the CES. Average saving rates of owners and nonowners of marketable financial assets are shown in table 6. The measurement of saving for owners of marketable financial assets in the SCF is at best a crude approximation because a capital gain on corporate equities produces a change in net worth that can only be removed by assuming that the value of each household's portfolio changed in line with the Standard and Poor's index. While this assumption is obviously absurd at the level of individual respondents, it is a useful approximation for equity holders as a whole. In any case, the interesting result is that the decline in the saving rate in the SCF is actually smaller among stock- and bondholders than it is among households with no marketable financial assets. The CES shows a decline in saving for households both with and without financial assets, and, while the absolute decline is larger for owners of financial assets, the relative declines in two groups' saving rates are very similar.

In order to investigate the influence of capital gains from homeownership, the SCF and CES samples are split into homeowner and nonhomeowner groups, and we included some disaggregation by age even though the size of the individual cells in the SCF is small. ${ }^{29}$ The results are shown in table 6 and are at least consistent with the argument that capital gains on housing may have contributed to lower saving rates. Saving rates of homeowners fell substantially in both surveys-a decline of 6.4 percentage points in the SCF and 5.5 percentage points in the CES. Also, the decline for homeowners is pronounced in the middle age group (aged 45-65), which is consistent with a finding by Joyce Manchester and

29. The effect of housing capital gains has been the subject of some previous analysis based on survey data. See, for example, Manchester and Poterba (1989) and Skinner (1989). 


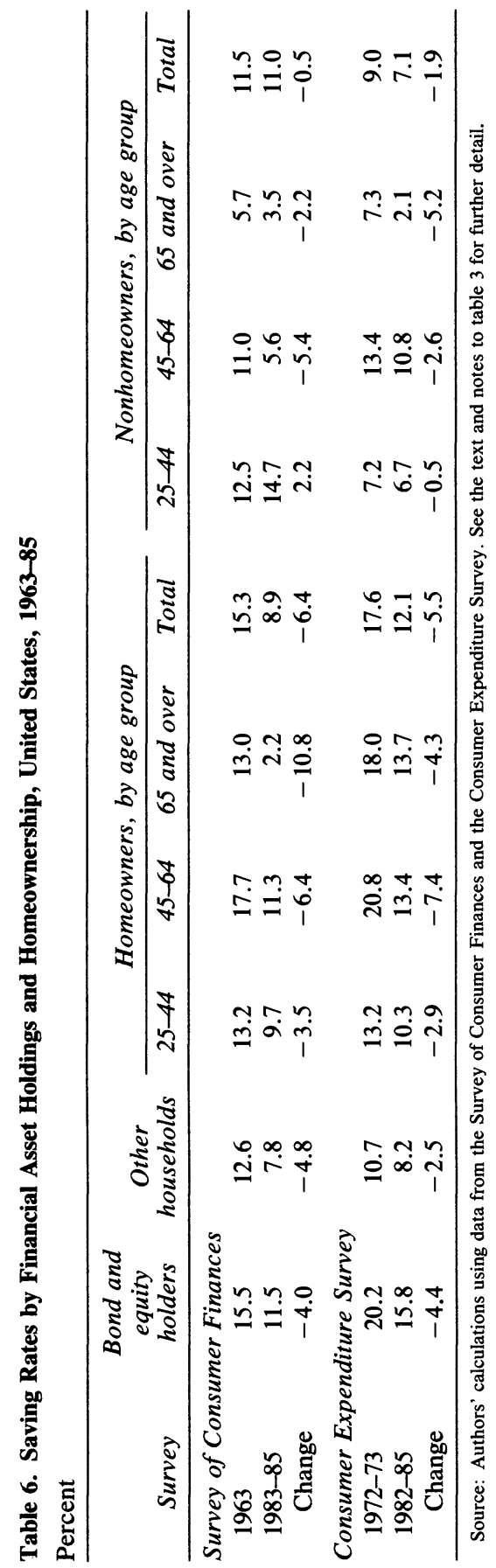


James Poterba that the incidence of second-mortgage borrowing is concentrated in that group. ${ }^{30}$ Saving rates of nonhomeowners fell less in both surveys- 1.9 percentage points in the CES and just 0.5 points in the SCF. The survey data thus provide some evidence that the boom in real-estate prices may have been a contributing factor to lower saving, but we find no evidence to support the claim that the jump in equity prices reduced household saving.

\section{International Evidence on the Decline in Saving}

The U.S. data strongly imply that efforts to explain the decline in household saving must emphasize general factors that affect a large proportion of all households. Explanations that rely on reduced saving by one demographic or economic group appear to be contradicted by the data. As mentioned earlier, however, the amount of survey information on U.S. household saving is very restricted. In addition, we have no assurance that the change in saving rates obtained from surveys, taken at two points in time, reflects the same phenomenon reported in the national accounts. Thus, we have supplemented the results for the United States with an analysis of similar surveys for Canada and Japan.

\section{Canada}

Recent Canadian saving has fluctuated over a much wider range than has saving in the United States. Personal saving, as reported in the Canadian national accounts, rose from slightly over 5 percent of disposable income in the late 1960 s to 15 percent in the early 1980s, before falling back to 10 percent in $1989 .{ }^{31}$ It is possible to identify some of the sources of the movement in saving rates by distinguishing between saving in formal retirement accounts and in other categories. While pensions and other forms of retirement saving are somewhat more

30. Manchester and Poterba (1989).

31. The large spike in 1982 is an anomaly that can be traced to a very large decline in household borrowing that was itself a response to very high nominal interest rates. The responsiveness of household borrowing to interest rates is generally much stronger in Canada than in the United States, primarily for institutional reasons. See Bosworth (1989). Unlike the United States, mortgage interest payments are not deductible for tax purposes in Canada, and most mortgages are of short maturity-commonly no more than five years. 
Figure 2. Components of Personal Saving, Canada, 1965-89

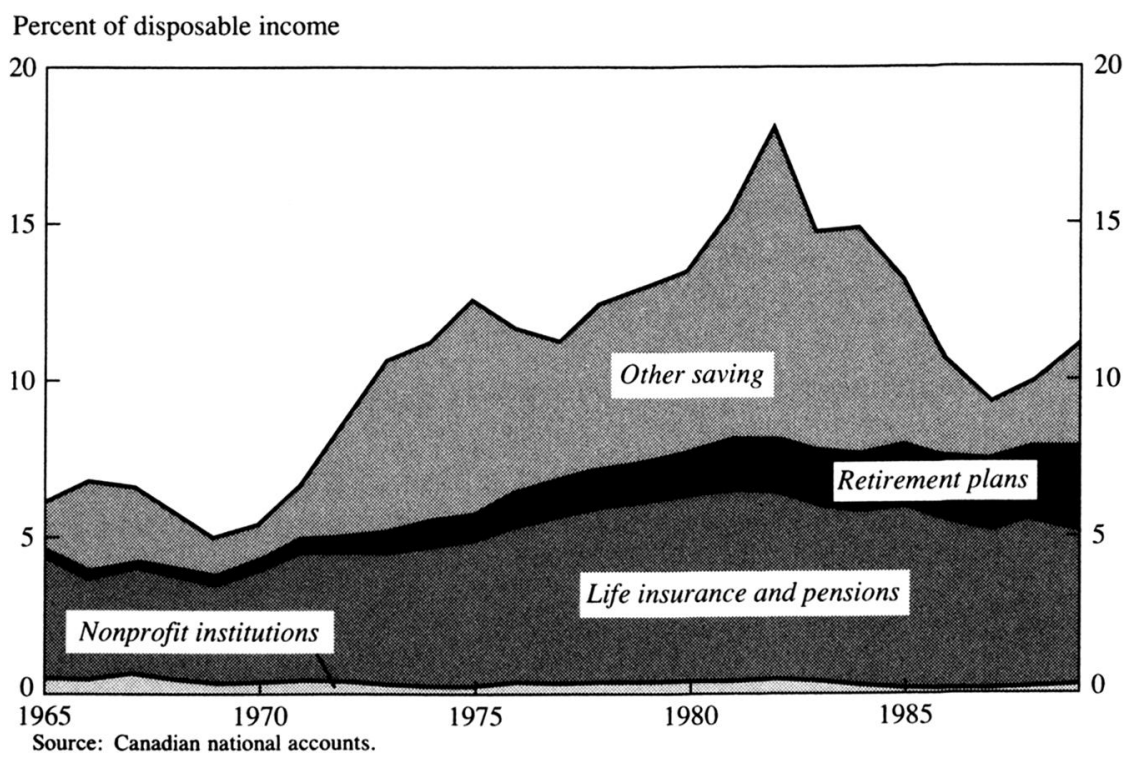

important in Canada than in the United States, the data displayed in figure 2 clearly indicate that the volatility of Canadian saving has been concentrated in nonretirement saving accounts. Movements in these types of accounts should be captured in survey responses concerning household saving and consumption behavior. The Registered Retirement Saving Plans (RRSPs), which expanded significantly in the 1970s, are similar to Individual Retirement Accounts (IRAs) in the United States, but they are a minor source of the variability in Canadian saving and only a secondary source of the secular increase in the overall rate.

Canada undertakes a periodic survey of household income and consumption expenditures, called Family Expenditure in Canada, that is similar to the U.S. Consumer Expenditure Survey. ${ }^{32}$ The Canadian survey makes a greater effort to obtain a full income-expenditure statement for each household sampled, and the quality of the data consequently seems generally superior to that for the United States. As in the United States, more information is obtained about expenditures than income because the survey serves as the main source of information

32. Household Surveys Division (1986). 
Table 7. Age Distribution of Saving and Income, Canada, 1969-86

Percent

\begin{tabular}{|c|c|c|c|c|c|c|c|}
\hline \multirow[b]{2}{*}{ Item } & \multirow[b]{2}{*}{$\begin{array}{l}\text { National } \\
\text { accounts }\end{array}$} & \multirow[b]{2}{*}{$\begin{array}{l}\text { Survey } \\
\text { total }\end{array}$} & \multicolumn{3}{|c|}{ Age group } & \multicolumn{2}{|c|}{$\begin{array}{c}\text { Alternative saving } \\
\text { measures }^{\mathrm{a}}\end{array}$} \\
\hline & & & $\begin{array}{c}\text { Under } \\
45\end{array}$ & $45-64$ & $\begin{array}{c}\text { Over } \\
64\end{array}$ & Alt 1 & Alt 2 \\
\hline \multicolumn{8}{|c|}{ Saving rate ${ }^{b}$} \\
\hline 1969 & 5.0 & 6.0 & 4.1 & 8.6 & 6.3 & 6.0 & 6.0 \\
\hline 1978 & 12.6 & 12.1 & 8.8 & 16.6 & 14.5 & 12.3 & 12.3 \\
\hline 1982 & 18.2 & 15.5 & 12.3 & 19.2 & 20.4 & 15.7 & 15.0 \\
\hline 1986 & 10.7 & 10.1 & 7.2 & 14.3 & 11.0 & 10.2 & 10.5 \\
\hline \multicolumn{8}{|c|}{ Population share } \\
\hline 1969 & $\ldots$ & 100.0 & 48.2 & 33.7 & 18.1 & $\ldots$ & $\ldots$ \\
\hline 1978 & $\ldots$ & 100.0 & 51.1 & 31.8 & 17.1 & $\ldots$ & $\ldots$ \\
\hline 1982 & $\ldots$ & 100.0 & 52.9 & 30.0 & 17.2 & $\ldots$ & $\ldots$ \\
\hline 1986 & $\ldots$ & 100.0 & 51.7 & 30.0 & 18.3 & $\ldots$ & $\ldots$ \\
\hline \multicolumn{8}{|c|}{ Relative income } \\
\hline 1969 & $\ldots$ & 100.0 & 110.0 & 110.2 & 54.4 & $\ldots$ & $\ldots$ \\
\hline 1978 & $\ldots$ & 100.0 & 107.3 & 112.0 & 55.9 & $\ldots$ & $\ldots$ \\
\hline 1982 & $\ldots$ & 100.0 & 106.4 & 112.4 & 58.2 & $\ldots$ & $\ldots$ \\
\hline 1986 & $\ldots$ & 100.0 & 104.4 & 117.3 & 59.3 & $\ldots$ & $\ldots$ \\
\hline
\end{tabular}

Source: Household Surveys Division (1986) and Canadian national accounts. The tabulations include all families and unrelated individuals.

a. Alt 1 shows the saving rate computed with 1969 demographic and relative income shares. Alt 2 is computed with 1969 demographic shares.

b. Saving equals after-tax income plus other money receipts minus consumption expenditures and gifts and contributions paid. It is shown in the table as a percent of after-tax income.

c. Relative income is the average after-tax income in each age group relative to the average over the whole sample.

for constructing the weights in the consumer price index. Our analysis is based on surveys for four different years between 1969 and 1986. The surveys represent both urban and rural households and use samples that range in size from 8,000 in 1982 to 15,000 in 1969 . We have been forced to reduce the number of age categories when calculating the influence of demographic changes because detailed age data for 1969 are unavailable, but this limitation has very little impact on our results. ${ }^{33}$

Table 7 presents estimates from both national accounts and survey data on the Canadian saving rate. The concepts of income and saving reflected in the Canadian survey differ from those in the Canadian national accounts for many of the same reasons discussed earlier with regard to U.S. surveys. Nonetheless, as the table shows, the average saving rate for all households in the survey changes over time in a pattern that closely parallels the movements in the saving rate measured in the national accounts. Both rates show a sharp increase in saving in the 1970s, followed by a decline in the 1980s. As in the U.S. Consumer

33. Households headed by someone under the age of 25 do have low saving rates, but their weight in the total is small. 
Expenditure Survey, the pattern of saving by age shows a humped distribution. Also in common with the U.S. pattern, the saving rate remains strongly positive for households headed by someone over age 65. The income of elderly households is well below the Canadian average, but so too is their consumption. In part, the lower consumption spending by the elderly can be traced to below-average rates of expenditure on consumer durables and housing. These households are presumably consuming out of a previously accumulated stock. But the evidence for a sharp decline in consumption after retirement remains even if durables and housing are excluded.

Tabulations of the Canadian saving data strongly confirm our findings from survey data in the United States. The time-series variation in the overall Canadian saving rate occurs because of very similar changes in the saving rates of households in all age groups. The change in the age and income distribution of the Canadian population has played a very minor role in accounting for the change in aggregate saving over time. In addition, there is no evidence that younger households are responsible for a disproportionate share of the decline in saving in the 1980s. If anything, the decline in saving among younger households has been less than that among older households.

Canadian saving rates do vary significantly by age. But table 7 shows that the Canadian age distribution has changed little since 1969. On the other hand, the distribution of income has moved in favor of older households. Overall, demographic factors account for little of the change in the aggregate saving rate. As we did for the United States, we can compute a precise measure of the influence of demographic and income changes using equation 1 . Two alternative measures of the overall saving rate, using the fixed age and fixed relative income distributions of 1969, are also shown in table 7. A comparison of these measures with the actual rate of saving, shown in the "total" column, confirms the insignificance of these factors as an explanation for the variation in saving. ${ }^{34}$

The tabulation of Canadian saving rates by income quintiles, shown in table 8 , indicates a pattern of saving similar to that in the United

34. We do not present an analysis of Canadian saving rates for different types of families, but the results are similar to those for the United States. Single-head families with children have low saving rates, but their average income is too low for this group's growth to have a major influence on the total saving rate. 
Table 8. Saving and Income, by Income Quintile, Canada, 1969-86

Percent

\begin{tabular}{lrrrrrr}
\hline & & \multicolumn{5}{c}{ Income quintile } \\
\cline { 3 - 7 } Item & Total & First & Second & Third & Fourth & Fifth \\
\hline Saving rate & & & & & & \\
1969 & 6.0 & -19.8 & -4.6 & 0.8 & 5.9 & 16.3 \\
1978 & 12.1 & -7.3 & -0.1 & 7.0 & 12.7 & 22.0 \\
1982 & 15.5 & -4.4 & 3.6 & 10.9 & 15.5 & 25.4 \\
1986 & 10.1 & -8.5 & -2.8 & 3.3 & 10.1 & 20.6 \\
Relative income & & & & & & \\
1969 & 100.0 & 32.0 & 65.3 & 93.2 & 121.6 & 187.9 \\
1978 & 100.0 & 34.5 & 65.7 & 93.6 & 122.0 & 183.9 \\
1982 & 100.0 & 33.8 & 63.8 & 91.2 & 122.2 & 189.0 \\
1986 & 100.0 & 33.6 & 61.6 & 88.6 & 122.7 & 193.5 \\
\hline
\end{tabular}

Source: See table 7 .

States. Again, saving rates are negative in the first two quintiles and rise with income. Most striking, the saving rates in the individual quintiles move up and down from one survey to the next in line with the changes in the overall saving rate. As shown in the bottom part of table 8, the distribution of family income in Canada is substantially more equal than in the United States-the ratio of average income in the highest quintile to that in the bottom quintile is about $6: 1$, compared with approximately 10:1 in the U.S. data. Nevertheless, there has been a secular rise in the proportion of income received by the top quintile, though that change was sufficient to account for only 0.2 percentage points of the rise in the saving rate between 1969 and 1986.

Finally, we tabulated the saving rates of homeowners and renters in Canada because of the suggestion in the U.S. data that homeowners may have accounted for a disproportionate share of the drop in saving. We might expect this phenomenon to be even more important in Canada because the credit restraints of the early 1980s should have fallen heavily on Canadian homeowners with short mortgage maturities. The saving rates (in percent) for homeowners and renters are given below.

$\begin{array}{ccc} & \text { Homeowners } & \text { Renters } \\ 1969 & 7.7 & 3.4 \\ 1978 & 14.5 & 6.9 \\ 1982 & 18.5 & 8.7 \\ 1986 & 13.2 & 3.8\end{array}$


While homeowners do have substantially higher rates of saving than tenants, the two saving rates change by roughly equal proportions between the individual survey years. ${ }^{35}$ In addition, the decline in the saving rate after 1982 is more pronounced for tenants than it is for homeowners. The results for Canada do not support the conclusion from the U.S. data that changes in saving rates are concentrated among homeowners, even though the two countries enjoy similar rates of homeownership.

\section{Japan}

Japan conducts two annual surveys that report information on the saving patterns of individual households. The Family Income and Expenditure Survey (FIES), conducted on a monthly basis, obtains diary information from individual households on a highly detailed set of family expenditures. ${ }^{36}$ Given the difficulties of accurately measuring business income, however, the portion of the sample that provides data on income is limited to those households headed by a worker and excludes the self-employed, farmers, retirees, and single-member households. In addition, because of the heavy burden of reporting, a sample family is surveyed for only six months, with regular monthly rotation.

A second supplementary survey, the Family Saving Survey (FSS) taken at the end of each year, gathers information on the flows and stocks of household savings and liabilities as well as on investments in fixed assets. The FSS asks for detailed information on the stocks of current assets as well as net purchases during the year. ${ }^{37}$ The FSS is thus most similar to the Survey of Consumer Finances in the United States. Furthermore, the FSS reports annual income and wealth holdings of the self-employed and retirees, as well as separate tabulations for households headed by wage and salary earners. This second survey therefore provides information on the saving of nonworker households, which is critical to investigating the role of retirees. Its primary disadvantage is that income information is limited to total household income before taxes. The FSS is available on a relatively consistent basis for each year

35. The timing of change in home prices was different in Canada than in the United States. In Canada, home prices rose more sharply in the 1969-78 period and declined from 1978 to 1986. See Engelhardt and Poterba (1990).

36. Management and Coordination Agency (1988).

37. Management and Coordination Agency (various years). 
after 1967 and includes separate tabulations for ten age groups and income quintiles.

We have relied primarily on data from the FSS. Saving is computed as the net change in financial assets minus the net change in financial liabilities plus the net purchases of physical assets, including housing. The survey measure of saving in corporate equities excludes unrealized capital gains and losses. ${ }^{38}$ We estimate family disposable income by computing the effective tax rate in each age category reported in the FIES. This rate is then applied to reported income from the FSS. This methodology seems reasonable in that the estimate of before-tax income of worker households in the saving survey is a relatively constant fraction of the income reported in the FIES. The mean ratio for the 1970-89 period was 1.068 , with a 0.016 standard deviation. While it is hard to defend our assumption that the tax rate is the same for worker and nonworker households, the measure of disposable income has no effect on the measure of saving and is used only to form the denominator of the saving rate. An error in measuring taxes is thus unlikely to distort the time-series pattern of saving rates. ${ }^{39}$

Figure 3 compares the survey measure of the household saving rate derived from the FSS to the rate shown in the Japanese national accounts. These two measures of the saving rate show a similar secular trend, rising up through the mid-1970s and then falling. However, the survey measure declines more sharply in the early 1980s and rises near the end of the period, while the national accounts measure declines throughout the decade.

The survey concept of the Japanese saving rate differs from the national accounts concept for many of the same reasons as in the United States. Published data are not available to investigate the importance of the conceptual differences, but the Japanese Economic Planning Agency reports that adjustments to the national accounts, using unpublished data, can account for the differences in the level of the two saving rates and would moderate the extent of decline in the NIA measure. The sharp decline and subsequent recovery of the survey measure in the early 1980 s remains unexplained, however.

The Japanese data are valuable because they let us examine changes

38. Changes in corporate equities are measured as stock purchases during the survey year minus stock sales during the same year.

39. The assumption of similar tax rates is particularly inappropriate for the older age group because retirees receive significant untaxed transfer income. 
Figure 3. Alternative Measures of Household Saving, Japan, 1968-89

Percent of disposable income

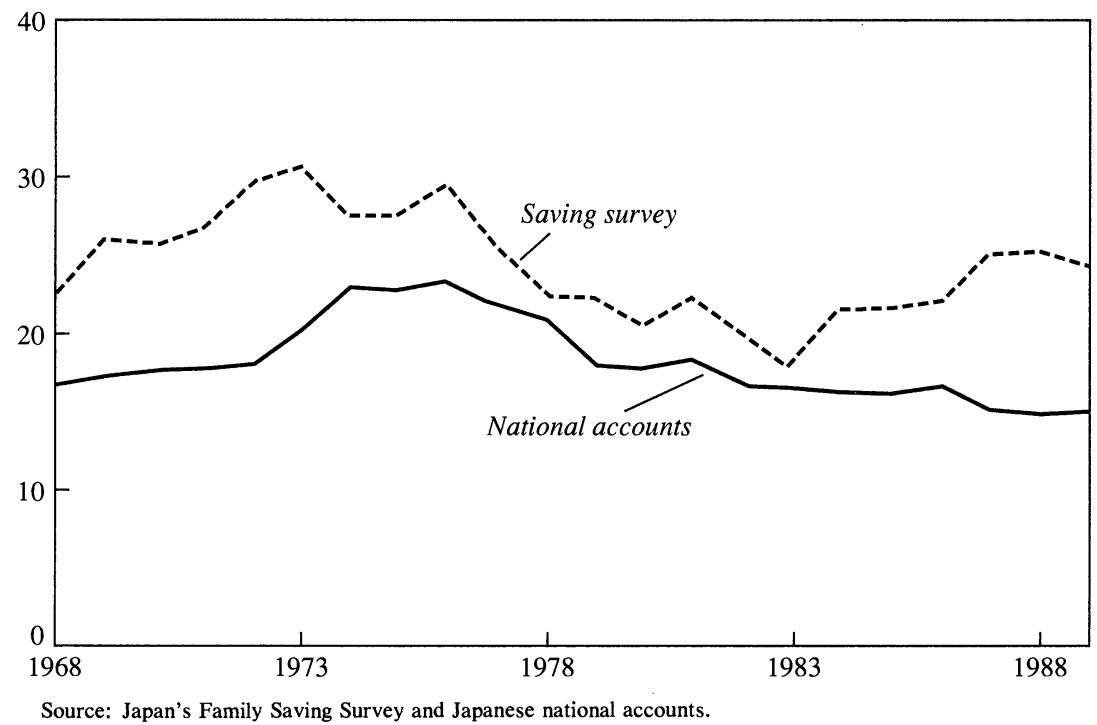

in age-specific saving rates annually over a twenty-year period. Because the FSS provides information on the number and relative income of households in each age bracket, we can compute a direct measure of the influence of demographic change on the overall saving rate.

Household saving rates grouped by the age of the household head are shown in table 9 for three periods: the early 1970s, the early 1980s, and the late 1980s. The data do show a slightly humped distribution of saving by age, but the extent of the difference among age groups is less than in the United States or Canada. It is also notable that the secular decline in Japanese saving is evident in all age groups, matching the findings from the other two countries.

Two features of the Japanese data can affect our interpretation of this pattern, however. First, the measure of saving available to us is based on the change in asset holdings excluding capital gains. It includes as saving the net transfer of wealth through inheritance, but inheritances are not included in income. Second, it is much more common in Japan for the elderly to move in with their children than in the United States or Canada. Such households are classified in Japan by the age of the adult 
Table 9. Age Distribution of Saving and Income, Japan, 1970-89

Percent

\begin{tabular}{|c|c|c|c|c|c|c|c|}
\hline \multirow[b]{2}{*}{ Item } & \multirow[b]{2}{*}{$\begin{array}{l}\text { National } \\
\text { accounts }\end{array}$} & \multirow[b]{2}{*}{$\begin{array}{c}\text { Survey } \\
\text { total }\end{array}$} & \multicolumn{5}{|c|}{ Age group } \\
\hline & & & $25-34$ & $35-44$ & $45-54$ & $55-64$ & $\begin{array}{c}\text { Over } \\
64\end{array}$ \\
\hline \multicolumn{8}{|c|}{ Saving rate } \\
\hline $1970-74$ & 19.4 & 28.1 & 23.4 & 29.1 & 25.1 & 34.8 & 31.3 \\
\hline $1980-84$ & 17.0 & 20.5 & 18.8 & 21.1 & 19.6 & 23.7 & 18.4 \\
\hline $1985-89$ & 15.4 & 23.6 & 22.0 & 25.0 & 21.6 & 27.8 & 18.2 \\
\hline \multicolumn{8}{|c|}{ Age distribution } \\
\hline 1970-74 & $\ldots$ & 100.0 & 20.6 & 34.2 & 23.3 & 14.8 & 7.3 \\
\hline $1980-84$ & $\ldots$ & 100.0 & 17.4 & 30.9 & 26.4 & 15.7 & 9.5 \\
\hline $1985-89$ & $\ldots$ & 100.0 & 12.9 & 30.3 & 25.5 & 19.2 & 11.9 \\
\hline \multicolumn{8}{|c|}{ Relative income } \\
\hline $1970-74$ & $\ldots$ & 100.0 & 80.2 & 98.2 & 117.3 & 107.5 & 94.4 \\
\hline $1980-84$ & $\ldots$ & 100.0 & 79.5 & 98.5 & 114.0 & 110.3 & 87.8 \\
\hline $1985-89$ & $\ldots$ & 100.0 & 77.7 & 97.0 & 118.0 & 107.3 & 81.7 \\
\hline
\end{tabular}

Source: Management and Coordination Agency (1988), Family Saving Survey from Management and Coordination Agency (various years), Japanese national accounts, and authors' calculations as explained in the text. Households are placed in an age group based on the age of the head of the household.

a. Saving is measured as the net accumulation of financial assets less the change in liabilities plus investment in tangible assets. It is expressed as a percent of after-tax income.

child. Thus, separate households headed by someone over 65 years of age are more likely to be unusually wealthy, and the growth in the number of such households over time reflects, in part, a social trend of reduced dependency of the retired elderly on their children.

The changing age distribution of Japanese households is shown in the middle of table 9. The changes are far more pronounced than in the United States or Canada. The proportion of households headed by someone under age 35 has declined by more than a third since the early 1970 s, and the proportion headed by someone over age 55 has increased by nearly 25 percent. ${ }^{40} \mathrm{On}$ the other hand, the distribution of household income, shown at the bottom of the table, has changed very little. There has been some decline in the relative income of younger and much older households, but the importance of these shifts is small.

Alternative measures of the trend in overall Japanese saving, based on these household survey data, are shown in figure 4 . The solid line shows the actual rate of total saving reported in the FSS. The dotted line represents the saving rate adjusted to keep the Japanese age distribution

40. Households headed by someone under the age of 25 are excluded from the table because of small sample size. They represent a small share of all households. 
Figure 4. Demographic Effects on Household Saving, Japan, 1968-89

Percent of disposable income

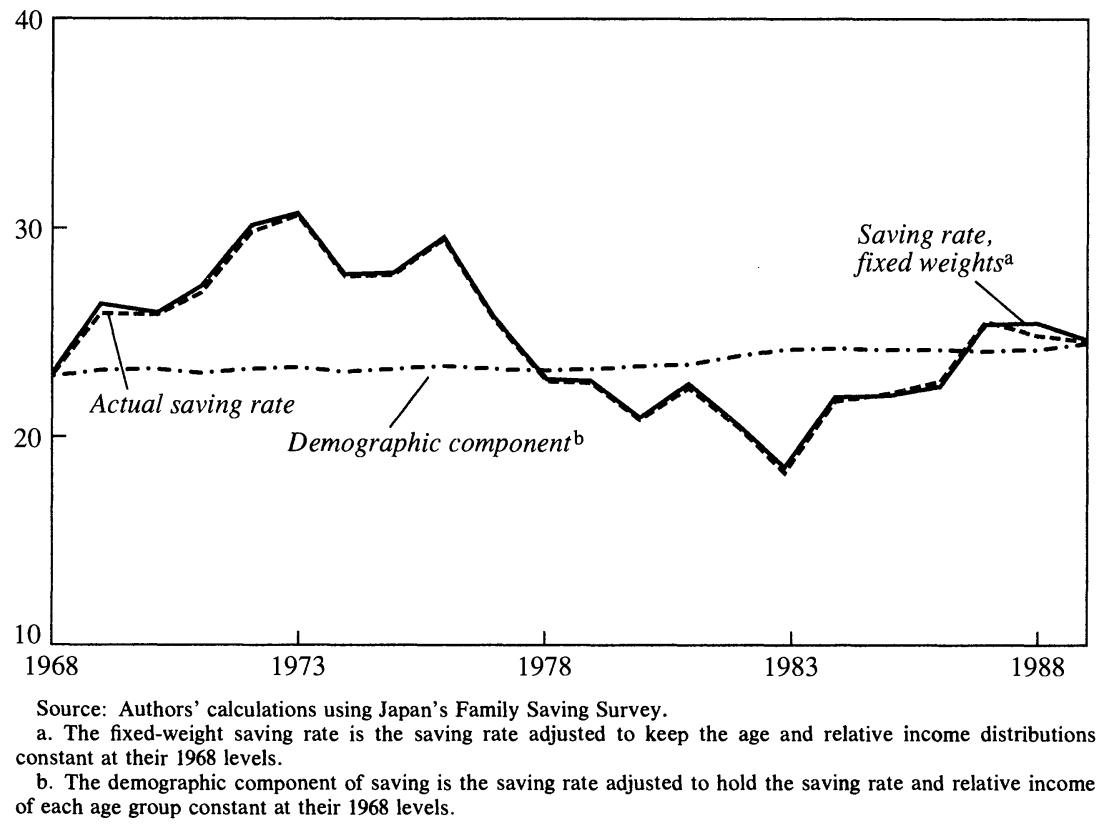

and relative income distribution constant at their 1968 levels (that is, $w_{i t}$ $=w_{i, 1968}$ and $y_{i t}=y_{i, 1968}$ ). (The choice of a base year for measuring $w_{i}$ and $y_{i}$ has no significant influence on the results.) The adjusted saving rate is almost indistinguishable from the actual rate, indicating that nearly all of the movement in the aggregate saving rate can be traced to the changes of saving rates within age groups. That is, essentially all of the variation in the saving rate is due to movements in $s_{i}$ alone. The nearly horizontal broken line represents the saving rate holding the saving rate and relative incomes of different age groups fixed at their 1968 levels (that is, $s_{i t}=s_{i, 1968}$ and $y_{i t}=y_{i, 1968}$ ). The influence of demographic change alone has been to increase the overall saving rate over the $1968-88$ period. ${ }^{41}$ More important, the differences in saving rates among age groups are simply not large enough to generate major

41. There has been no significant change in the distribution of household income by age of the household head. That specific result is not shown in the figure. 
demographic effects on the aggregate saving rate. While there is a secular correlation between the aging of the Japanese population and the recent decline in household saving, the relationship does not appear to be causal.

The influence of an increased number of retirees on the saving rate is potentially obscured in the Japanese data by the tendency for elderly parents to live with their children, a factor that spreads retirees' effect on saving over younger households. This explanation for the survey results is unsatisfactory, however, because of the uniformity of the decline in saving across the entire age spectrum. If the increased number of elderly were contributing to lower saving rates, we would expect to see the decline concentrated in those households most likely to have elderly parents. In addition, the likelihood that parents will live with their children is declining, as suggested by the large increase in the number of elderly households in the survey.

The distribution of Japanese household saving rates by income quintile is shown in table 10. The major difference from similar tabulations for the United States and Canada is that Japanese household saving rates are strongly positive in the lower two quintiles, rather than negative as in North America. Household saving rates do rise with income, but the extent of the increase is comparatively small. In part, this difference may be due to the smaller amount of welfare payments in Japan, which are often underreported in the American and Canadian surveys. Still, it appears that part of the explanation for high saving in Japan is the high saving rate of low-income groups. It is also interesting to note that the range of relative incomes, while less than in the United States, is comparable to that in Canada. Nonetheless, the Japanese results are similar to those for North America in implying that saving rates have moved up and down across virtually the entire income distribution. ${ }^{42}$ Again, there appears to be strong evidence of a common influence on changes in saving rates over time.

42. The saving rates reported for the lower quintiles of the all-households sample would appear to be an exception, but the sharp drop in the saving rate for the 1980-88 period is concentrated just in two years. As mentioned previously, it is difficult to measure the saving of the self-employed. No such sharp decline is shown in the data for households headed by a wage and salary worker. 
Table 10. Japanese Saving and Income, by Income Quintile, 1970-89

Percent

\begin{tabular}{|c|c|c|c|c|c|c|}
\hline \multirow[b]{2}{*}{ Item } & \multirow{2}{*}{$\begin{array}{c}\text { Survey } \\
\text { total }\end{array}$} & \multicolumn{5}{|c|}{ Income quintile } \\
\hline & & First & Second & Third & Fourth & Fifth \\
\hline \multicolumn{7}{|c|}{ All households } \\
\hline \multicolumn{7}{|c|}{ Saving rate } \\
\hline 1970-74 & 28.1 & 24.6 & 23.2 & 26.3 & 27.3 & 31.2 \\
\hline $1980-84$ & 20.5 & 10.9 & 18.7 & 19.5 & 20.5 & 23.8 \\
\hline 1985-89 & 23.6 & 18.0 & 25.0 & 21.8 & 24.2 & 24.6 \\
\hline \multicolumn{7}{|c|}{ Relative income } \\
\hline 1970-74 & 100.0 & 42.9 & 67.2 & 86.8 & 112.1 & 190.9 \\
\hline $1980-84$ & 100.0 & 43.7 & 68.5 & 88.4 & 113.3 & 186.2 \\
\hline $1985-89$ & 100.0 & 39.9 & 65.3 & 87.8 & 114.8 & 192.1 \\
\hline \multicolumn{7}{|c|}{ Worker households } \\
\hline \multicolumn{7}{|c|}{ Saving rate } \\
\hline $1970-74$ & 25.5 & 21.3 & 20.7 & 24.1 & 26.1 & 28.4 \\
\hline $1980-84$ & 21.4 & 15.7 & 19.0 & 21.0 & 21.2 & 24.6 \\
\hline 1985-89 & 23.2 & 16.0 & 22.2 & 21.8 & 24.3 & 25.2 \\
\hline \multicolumn{7}{|c|}{ Relative income } \\
\hline $1970-74$ & 100.0 & 50.7 & 72.4 & 90.1 & 112.6 & 174.2 \\
\hline $1980-84$ & 100.0 & 51.6 & 73.4 & 91.6 & 114.0 & 169.3 \\
\hline $1985-89$ & 100.0 & 48.2 & 71.9 & 91.8 & 115.1 & 172.3 \\
\hline
\end{tabular}

Source: See table 9.

\section{Implications for the Decline in Saving}

Our analysis leads to several conclusions about the decline in household saving rates. First, the data provide no support for arguments that the decline can be traced to reduced saving on the part of specific groups in the population, such as members of the baby-boom generation. We find, instead, a common pattern of reduced saving within nearly all groups examined. The drop in saving was, however, far larger among households headed by someone over 45 than among younger households. This pattern of saving decline could be attributable to the rise in real rates of return in the 1980s. Older households, with substantial asset holdings at the start of the decade, might respond to higher returns by raising their rate of consumption out of current income. This wealth effect of higher real returns would be far smaller among younger families, who possessed fewer assets when rates of return soared.

At the same time, we find that shifts in the composition of the population between groups that are traditionally high savers, such as 
married couples and the middle-aged, and groups that are low savers, like the young and the retired, have been inconsequential as an explanation for the decline. We thus reject the prediction that the private saving rate will necessarily rise in the near future as the large baby-boom cohort enters middle age. In fact, comparing the variability of each group's saving rate over time to the difference in saving rates between the groups leads us to question the view that the overall saving rate will necessarily decline in the longer term as the population ages. An increase in the proportion of elderly households could easily be offset by increased rates of saving within various age groups, including the elderly themselves. The insignificance of demographic factors as an explanation for past changes in the saving rate in the United States is equally applicable to saving in Canada and Japan.

We also find no evidence that U.S. saving rates have changed by disproportionate amounts in different parts of the income distribution. Instead, the saving rates of different income classes have for the most part moved together. And, in the cases of Canada and Japan, saving rates of different income classes have moved both up and down together.

Our analysis of the role of capital gains as a factor in the decline of saving is less conclusive. We find no support for the idea that reduced saving within the United States was concentrated among consumers who held financial assets, the values of which soared in the 1980s. In any case, most of the drop in U.S. saving occurred before the boom in equity markets. On the other hand, survey data for the United States-though not for Canada-indicate that sharply higher home prices may have contributed to the drop in saving. The falloff in saving was much more severe among U.S. homeowners than among renters, suggesting that capital gains on homes may have displaced some household saving.

It is possible that these results simply reflect statistical problems in the surveys. If the results were based solely on a single survey, such as the CES, which obtained saving as the difference between income and consumption, the drop in the saving rate could be explained away as the result of differential trends in the misreporting of consumption and income. For that reason, we have taken some care to evaluate the quality of the survey data. Our analysis suggests that changes in the quality of the data are not large enough to explain the pattern of results observed. Moreover, our conclusions gain added credibility because they are based on two completely different survey approaches to measuring household 
saving in the United States. The additional analyses of survey data from Canada and Japan confirm the main findings from the United States. The uniformity of results from such a wide variety of surveys seems reassuring.

The striking result that emerges from this study is the extent to which the saving rates of most population subgroups change in parallel over time. This result suggests that the decline in saving must involve one or more factors that affect the vast majority of households uniformly. In seeking an explanation for the drop in saving, we are thus drawn back to macroeconomic factors, rather than the demographic and microeconomic determinants that many economists currently find so attractive.

One possible explanation for lower saving involves slower income growth. Most economists would agree that saving rates should be positively associated with income changes in the short run because of the dominant role played by transitory income movements over the business cycle. But this positive short-run association cannot provide a satisfactory explanation for the secular decline in saving, which has now lasted more than a decade. Is it possible that a reduction in the long-term growth rate, arising from slower productivity or labor force growth, has reduced saving? The secular decline in income growth has been pronounced in the United States since the early 1970s, and it is a phenomenon shared by other industrial countries.

The original formulation of the life-cycle consumption model by Franco Modigliani and others implied a positive relationship between aggregate saving rates and aggregate income growth. The relationship was a key factor in subsequent studies seeking to account for international differences in private saving rates. ${ }^{43}$ The connection between saving and income growth, however, resulted solely from the process of aggregation: an increase in the rate of income growth, whether because of increases in population or productivity, raised the incomes of workers (who save) relative to those of retirees (who dissave), thus boosting the weights attached to saving cohorts and reducing the weights attached to dissaving cohorts in the determination of aggregate saving. There is no implied association between saving and expected income growth at the level of the individual household. We have already shown, however,

43. The argument is laid out in Modigliani (1966), and empirical support is provided in Modigliani (1970), Modigliani and Sterling (1983), and Feldstein (1980). 
that the redistribution of income among saving and dissaving age groups has played only a small role in recent movements in the private saving rate. Thus, the link suggested by Modigliani and others explains at best a minor part of the recent decline in saving.

In addition, James Tobin and M. J. Farrell challenged the generality of even this link, noting that it depended upon Modigliani's assumptions that consumers do not anticipate higher levels of future income and that they dissave only during retirement. ${ }^{44}$ In the traditional life-cycle model, current consumption is a function of lifetime resources, which is the sum of current wealth and the present discounted value of expected future labor income. Modigliani's version of the life-cycle model, however, assumes that consumers do not incorporate expected future income growth into their computation of lifetime resources. Alternatively, under the assumption of perfect foresight, expectations of higher future income growth will lead individual households to consume more today, postponing saving until it is less costly in terms of forgone consumption. That is, expectations of higher income growth should reduce current saving within each age cohort, offsetting the effect arising from the redistribution of income toward high-saving groups. ${ }^{45}$

In evaluating the effect of changes in income growth on saving behavior we must therefore consider two separate influences: the impact of income growth on the behavior of an individual household and its effect on the distribution of income across different age cohorts. If individual households are forward-looking in making consumption decisions, their current saving should be negatively related to the expected rate of income growth. On the other hand, if expectations are static, as assumed by Modigliani, a household's current saving rate is unaffected by income growth. In both models the redistribution of income in favor of wage earners, who save, and away from retirees, who dissave, contributes toward a positive relationship between the aggregate saving rate and income growth. In simulation models that incorporate forwardlooking expectations, Tobin found that the within-cohort effect domi-

44. Tobin (1967) and Farrell (1970).

45. The importance of the within-cohort negative effect of income growth will depend upon the age of the cohorts enjoying faster income growth. For those who are close to retirement, the present value of expected future income growth will be small relative to current wealth. The importance of this effect may also be limited among the young if they are constrained in their opportunities to borrow against future earnings. 
nated, producing a negative overall relationship between income growth and aggregate saving. The results in this paper also imply that the effects of income redistribution are comparatively minor, supporting Tobin's conclusion.

Most empirical research suggests that the life-cycle hypothesis is correct in emphasizing that households discount short-run fluctuations in their income when determining current consumption and that retirement is one important motive for saving. There is competing evidence, however, that consumption is more volatile and closely related to current income changes than would be consistent with the complete smoothing of consumption over full lifetime resources. ${ }^{46}$ While households may be aware of the age profile of earnings for their own occupations when planning their saving, few of them appear to incorporate information on variations in the growth of economywide earnings into their expectations. Instead, we observe a tendency for households to steadily, but gradually, build up their wealth, increasing their rates of saving in peak earning years and as they approach retirement age. The implication of the life-cycle model that households have a target wealth-income ratio that increases up to retirement appears valid; but the assumption of the forward-looking expectations version that the target at each age is negatively affected by income growth lacks empirical support. ${ }^{47}$

If there is a reasonably stable wealth-income target at each age, it would not be surprising if private saving has an accelerator component similar to that of investment. Thus, the rate of saving would rise and fall with the rate of the growth of income. If

$$
\begin{aligned}
& S_{t}=W_{t}-W_{t-1}, \text { where } \\
& W=\beta Y ;
\end{aligned}
$$

then

$$
\begin{aligned}
S_{t} & =\beta\left(Y_{t}-Y_{t-1}\right), \text { and } \\
S_{t} / Y_{t} & =\beta\left(Y_{t}-Y_{t-1}\right) / Y_{t} .
\end{aligned}
$$

Thus, if there is a stable wealth-income target at each age, $\beta$, saving rates will be positively related to the rate of income growth. Since the

46. See, for example, Hall and Mishkin (1982), Skinner (1988), Zeldes (1989), and in particular Carroll and Summers (1989).

47. Carroll and Summers (1989) and Bosworth (1990). 
household wealth-income ratio is about 3.5 , we would expect the saving rate to change in the long run by about 3.5 percentage points for every 1 percent change in the growth rate. Income per capita grew at a rate of 3.2 percent annually between 1960 and 1973, compared with just 1.5 percent annually from 1972 to the present. If at a given age each household attempted simply to hold the ratio of income to wealth constant, the secular decline in saving would be about 6 percentage points of incomemore than we have observed in the United States. It is noteworthy that the decline in saving has not been reflected in a lower wealthincome ratio in this country, even if we exclude capital gains during the 1980s.

The hypothesis that slower income growth is the cause of lower saving is attractive for two reasons. First, if true it would explain a dual phenomenon that is nearly universal among major industrial countries: rates of both saving and income growth have been simultaneously declining. We need some such cause to account for the pervasiveness of the decline in saving rates. Second, this hypothesis would help explain the drop in saving across such a broad cross-section of householdsyoung and old, rich and poor, equity holders and debtors. If the decline in saving rates does result from slower rates of economic growth, we should be extremely skeptical that private saving will recover anytime soon. The problem is that the hypothesis is in direct conflict with popular theoretical models of consumers who base their decisions on forwardlooking, rational expectations.

\section{APPENDIX}

\section{Description of the Data}

IN THIS APPENDIX we document the adjustments to national income account (NIA) data required to make these data compatible with the "survey" concepts of saving rates. The areas that are treated differently in the NIA and survey data involve employer contributions to pension funds, homeownership, depreciation, and third-party payments. The appendix also describes the Consumer Expenditure Survey and the Survey of Consumer Finances. The appendix concludes with an analysis of the quality of the data from the surveys. 
Table A1. Translation of National Accounting Concepts of Income and Consumption to a Cash Accounting Basis, United States, 1989

Billions of dollars, except where noted

\begin{tabular}{|c|c|c|c|}
\hline Item & $\begin{array}{c}\text { National } \\
\text { accounting } \\
\text { concept }\end{array}$ & Adjustments & $\begin{array}{c}\text { Cash } \\
\text { accounting } \\
\text { basis }\end{array}$ \\
\hline $\begin{array}{l}\text { Wages and salaries } \\
\text { - Imputations }(\mathrm{t} 8.9,40) \\
\text { Adjusted value }\end{array}$ & $2,573.2$ & 11.5 & $2,561.7$ \\
\hline $\begin{array}{l}\text { Plus: other labor income } \\
\text { - Employer contributions }(\mathrm{t} 6.13,20) \\
\text { + Benefits paid }(\mathrm{t} 6.13,28) \\
\text { - Group health benefits }(\mathrm{t} 6.13,30) \\
\text { Adjusted value }\end{array}$ & 241.9 & $\begin{array}{l}237.1 \\
347.0 \\
155.6\end{array}$ & 196.2 \\
\hline $\begin{array}{l}\text { Plus: proprietor income } \\
\text { - Capital cons. adj.-farm }(\mathrm{t} 1.14,14) \\
\text { - Capital cons. adj.-nonfarm }(\mathrm{t} 1.14,16) \\
\text { - Imputations }(\mathrm{t} 8.9,46) \\
\text { Adjusted value }\end{array}$ & 379.3 & $\begin{array}{r}-7.7 \\
32.8 \\
8.3\end{array}$ & 345.9 \\
\hline $\begin{array}{l}\text { Plus: rental income } \\
\text { - Capital consumption adjustment }(\mathrm{t} 1.14,19) \\
\text { - Owner-occupied rental income }(\mathrm{t} 8.6,4) \\
\text { Adjusted value }\end{array}$ & 8.2 & $\begin{array}{r}-55.8 \\
15.8\end{array}$ & 48.2 \\
\hline Plus: dividend income & 114.4 & & 114.4 \\
\hline $\begin{array}{l}\text { Plus: interest income } \\
\text { - Imputed rental income }(\mathrm{t} 8.8,48) \\
\text { - Nonprofit institutions }(\mathrm{t} 8.14,7) \\
\text { Adjusted value }\end{array}$ & 643.2 & $\begin{array}{r}252.2 \\
36.5\end{array}$ & 354.5 \\
\hline $\begin{array}{l}\text { Plus: transfers } \\
\text { - Hospital and supplemental medical }(\mathrm{t} 3.11,5) \\
\text { - Military medical insurance }(\mathrm{t} 3.11,17) \\
\text { - Other federal transfers }(\mathrm{t} 3.11,27) \\
\text { - Public assistance medical care }(\mathrm{t} 3.11,34) \\
\text { - Other public assistance }(\mathrm{t} 3.11,39) \\
\text { - Education transfers }(\mathrm{t} 3.11,40) \\
\text { - Employment and training }(\mathrm{t} 3.11,41) \\
\text { - Business transfers }(\mathrm{t} 1.9,7) \\
\text { Adjusted value }\end{array}$ & 636.9 & $\begin{array}{r}97.9 \\
1.3 \\
11.9 \\
62.9 \\
2.7 \\
4.8 \\
1.0 \\
32.4\end{array}$ & 422.0 \\
\hline Less: personal contributions for social insurance & 212.8 & & $\begin{array}{c}212.8 \\
\text { (Continued) }\end{array}$ \\
\hline
\end{tabular}

\section{Adjustment of NIA Data}

Four major adjustments must be made to NIA data to bring them closer to the saving recorded on household surveys; the adjustments for 1989 are presented in table A1. First, national accounting methods attribute the accumulation of reserves within private pension and welfare funds as household saving. The NIA counts employer contributions to 


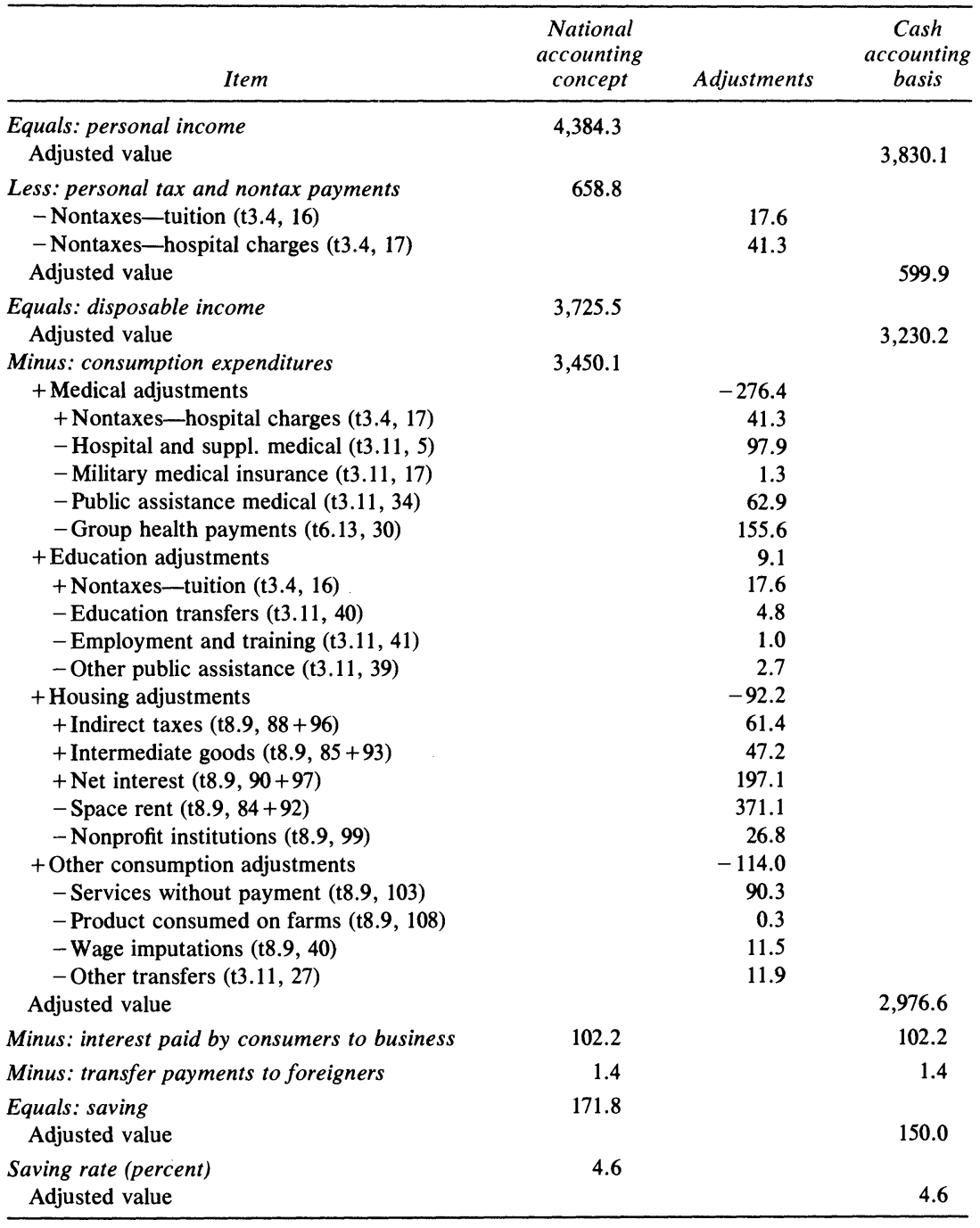

Source: National Income and Product Accounts. Symbols in parentheses refer to NIA table and line numbers.

these funds as a component of employee compensation and records the investment income of the funds as personal interest income. In a household survey, by contrast, respondents report the cash benefit payments from the funds as income, but do not report as income employer contributions to the funds or the investment income of the funds. The accumulation of reserves in the funds is thus excluded from both income 
and saving in the household surveys. When there is a positive accumulation in pension reserves, as there has been in recent decades, the survey measures of income and saving will be lower than the equivalent measures in the national accounts. The adjustment we make to the national accounts to eliminate this discrepancy is fairly straightforward.

Second, homeownership is treated as a business in the national accounts. Rental costs are an imputed part of consumption outlays. All maintenance, depreciation, property taxes, and mortgage interest expenses are allocated as business expenses. The residual net profit of homeownership, if any, is counted as part of personal rental income. This treatment of homeownership will have little impact on saving as long as the residual net profit is small. In recent years, homeowners have suffered a net loss on homeownership in the NIA; expenses have exceeded imputed rental income, thus reducing both income and saving below the levels that would be recorded in a household survey. In addition, the surveys ignore most elements of housing depreciation, because depreciation is not paid for with a cash outlay. The surveybased estimate of saving, obtained as the difference between income and consumption expenditures, is thus higher than that in the national accounts.

Third, the national accounts measure business income after deducting capital depreciation at current replacement costs rather than at historical cost as done in U.S. tax law. Household survey reports of net business income probably reflect private accounting practice, which is driven by tax law. Since the tax law frequently provides for a more generous depreciation allowance than the national accounts, the surveys may show a lower level of net business income and saving for the selfemployed.

Finally, a substantial number of third-party payments-particularly for medical care-are added to both household income and expenditures in the national accounts. These payments are seldom recorded in the household surveys. Because the adjustments affect both income and consumption by the same amount, they have little effect on saving.

\section{Consumer Expenditure Surveys}

Our analysis is based on U.S. data from the 1972 and 1973 Consumer Expenditure Surveys and from more recent CES stretching over the 
period from 1982 through 1985 . The sample drawn in the survey is a stratified random sample that is intended to represent all urban and rural households in the United States. Because of budgetary constraints in the early 1980s, however, only urban households were sampled during several early quarters of the decade. In order to keep our samples strictly comparable over time, we have restricted our analysis to urban households, which comprise 83 percent of all households and account for a somewhat higher percentage of consumption and income.

The 1972-73 surveys were conducted on a calendar-year basis, using a separate sample of about 10,000 consumer units, or households, in each of the two years. In the 1980 s new households were added to the survey on a continuous basis, so the income and consumption of a particular household did not necessarily cover a single calendar year. Allowing for nonresponses (including vacancies), the number of usable interviews covers between 5,000 and 6,700 households a quarter. Respondents are weighted to reflect their probability of being included in the sample, and the sums of weights within particular age, sex, and racial groups are calibrated to match those in the Current Population Survey.

The Census Bureau attempts to interview households included in the CES five times over the course of a year. The first interview provides data on the household's baseline characteristics, which are used to classify the household for analysis and as a check on future responses about new purchases of consumer durables. None of this expenditure information appears on the public use tapes available to us. In each subsequent interview, retrospective information is obtained about expenditures during the previous quarter. Interviewers collect family income information on the second and fifth quarterly interviews. Unfortunately, the data tapes for the 1980 s contain top-coded values on some income items for households with high reported incomes. Income and consumption values above some top-code level, such as $\$ 100,000$ a year, are recorded on the tape as simply $\$ 100,000$. The exceptional severity of the top coding has led us to exclude data from 1980 and 1981, but the top coding has only a minimal effect on the surveys conducted after 1981. We also exclude from the 1972-73 sample individual households with an absolute value of saving greater than $\$ 100,000$. Such values of household saving are by definition excluded in 1982-85 because of the top coding of income in that period.

To make the data usable in our analysis, we have rearranged the structure of the original data. Extensive restructuring is needed to make 
the data comparable to CES data collected in the 1970s; as a result, our tabulations do not correspond to those published by the Bureau of Labor Statistics. The quarterly files from the 1980 s were processed to construct data records for each household on a full reporting-year basis, rather than on a quarterly basis. Thus, each household is identified by the quarter in which it first contributed usable consumption information; information from the subsequent three interviews is then matched with this initial consumption information and included on the same household record. The income reported in the fifth quarterly interview covers exactly the same period covered by the consumption data; it is the income we use in our analysis. ${ }^{48}$ Because the surveys in the 1980 s did not obtain accurate measures of income tax liabilities, we have been forced to impute income taxes using information on family characteristics, taxable income reported in the fifth interview, and the relevant tax laws of each year. ${ }^{49}$

Our sample consists of the urban households drawn in both the 197273 surveys and the 14 separate quarterly samples entering the CES between the first quarter of 1982 and the second quarter of 1985 . The 13 quarterly samples entering the CES since 1986 could not be used in this study because of an apparent decline in the quality of income and consumption reports. The initial number of households entering the survey in each quarter during the 1980s was approximately 1,200. Because of attrition and incomplete income or consumption reporting, the usable sample in each quarter was reduced to about $650-850$ households. We adjusted the sample weights in the final analysis file to reflect the sample loss caused by attrition. ${ }^{50}$

The quarterly samples in the 1980 s are too small for any disaggregate analysis, so we combined the samples from contiguous quarters. The combination of samples from different periods gives rise to a complica-

48. Our estimates of aggregate income differ therefore from those reported in the published summaries of the CES data. Instead of reporting the annual income totals obtained in the fifth interview, the BLS averages in many responses taken from the second interview. However, the second interview collects income information covering an earlier period than that covered by the consumption data, so we cannot use it in our analysis. Our procedure is equivalent to the one used by the BLS in the 1972-73 surveys.

49. The 1972-73 surveys include good information on tax liabilities. To ensure that the tax data for the 1980s would align with those from the 1970s, we use the ratio of personal taxes to personal income from the national accounts as an index to adjust the level of the average tax rate in each sample from the 1980s.

50. A more complete description of the data set is provided in Sabelhaus (1990a). 
tion, however. Inflation and rising real incomes will tend to increase the implicit weights of observations that are drawn in later quarters. To minimize this influence, we have deflated the incomes and consumption expenditures reported by households drawn in later quarters. Our deflator was calculated based on the rate of increase in nominal per capita disposable income reported in the national income accounts. Income and consumption in the samples for the 1980 s were deflated by 1982 (first quarter) dollars, and income and consumption in the samples for the 1970s were deflated by 1972 dollars. For analytical purposes, the data were combined into two samples: 1972-73 (14,079 cases) and 198285 ( 9,739 cases). At the end of this appendix we consider the accuracy of the income and consumption data in the CES.

\section{Survey of Consumer Finances}

The 1963 Survey of Financial Characteristics of Consumers and the 1983 Survey of Consumer Finances were undertaken to estimate the asset holdings and debt obligations of a nationally representative sample of U.S. families. The data permit us to analyze the net financial position of families, their holdings of various types of assets, and the level and sources of their debt obligations. Both surveys were followed by reinterviews with many of the original respondents. Unfortunately, the 1986 reinterview managed to cover only a subsample of original respondents and was limited to a relatively short telephone questionnaire. Nonetheless, interviewers succeeded in maintaining a high degree of participation among high-income households. ${ }^{51}$ The 1986 SCF reinterview sample includes 2,536 households, while the 1963 reinterview covers 1,679 households. These are the samples available to us for analysis.

In spite of the obvious care used in collecting the data, many respondents reported wealth levels on the two SCF reinterview surveys that are difficult to reconcile with their reported incomes or receipts of gifts and inheritances between the two surveys. Although some of these reports were no doubt accurate, many were probably incorrect. We excluded certain classes of respondents to minimize the impact of

51. See Avery, Elliehausen, and Kennickell (1988) and the citations they mention for further details. 
reporting error. All households headed by someone under the age of 25 were excluded, as were households in which the head reported a change in marital status between the two surveys. We also excluded the few households that reported saving, exclusive of capital gains, that exceeded their income plus reported gifts between the two surveys. An important exclusion is our elimination of households with substantial wealth in their own businesses. Not only is the reported income from such businesses subject to great error, the valuation of the business assets is also problematical. We therefore excluded those households for which the value of own business exceeded 10 percent of the household's initial wealth. (This particular restriction eliminated 339 households in the 1963 survey and 541 households in the 1986 survey.) Taken together, the sample exclusions left us with a total of 1,211 households in 1963 and 1,806 households in 1986.

An estimate of saving obtained by comparing wealth holdings at two points in time is not comparable with saving measured in the national income accounts because the latter measure excludes capital gains and losses. In order to calculate a household's saving exclusive of capital gains and losses, it is necessary to form an estimate of capital gains from the SCF data. We estimated such gains for owners of corporate stocks by assuming that equity holders on the initial interview should have experienced gains on their original holdings in proportion to the percentage rise in the Standard and Poor's index between the first and second interviews. Obviously, this assumption will overstate gains for some households and understate gains for others. On balance, however, it should provide a reasonable estimate of gains for average households. Questions in the follow-up SCF interview make it possible to trace the sources of change in the value of real property, including additions to old properties, sales, and purchases of new properties. Corporate bond holdings were reported at book value, both on the initial and follow-up surveys.

\section{Quality of the Survey Data}

The Census Bureau and BLS have published detailed analyses of the consumption data reported in the CES, and the Federal Reserve has issued similar reports on the quality of the wealth data contained in the 
SCF..$^{52}$ Robert Avery, Gregory Elliehausen, and Arthur Kennickell show that estimates of aggregate family holdings of most financial assets and debts calculated from the full SCF compare favorably with estimates from the Flow of Funds. ${ }^{53}$ Publicly traded stock and bond estimates are within 2 percent of the Flow of Funds totals. Mutual fund shares, home mortgages, and installment debt also compare closely. The SCF totals do differ for checking and saving accounts, real estate, household-owned businesses, and other household debt. The SCF totals may actually be preferable to those in the Flow of Funds in the case of depository accounts and household debt, but it is likely that the SCF estimates of business and real-estate holdings are deficient. For that reason, we exclude respondents with substantial business assets.

Average money income reported in the SCF is somewhat higher than income reported in the CPS, the Census Bureau's main source of information on the distribution of household income. The difference is primarily due to defects in the CPS rather than the SCF. Some sources of income, such as wages and salaries and government transfers, are slightly underreported in the SCF. But most sources of income for which there is a large discrepancy between the totals on the SCF and the CPS are much more accurately reported on the SCF. In particular, total business income, dividends, and trust and rental income are much higher on the SCF than the CPS. These income items are known to be poorly recorded on the CPS. ${ }^{54}$ The better performance of the SCF can undoubtedly be traced to the enrollment of a high-income subsample in that survey. On balance, the SCF appears to provide a fairly accurate picture of the American wealth and income distribution at a given point in time. Its accuracy in measuring changes in household assets is less well documented.

The saving data in the CES have not been examined as extensively as the wealth data in the SCF, although the Census Bureau and BLS have compared the consumption totals recorded in the CES with totals reported in external data sources. ${ }^{55}$ We have partially replicated the

52. See Pearl (1978, 1979), Gieseman (1987), and Avery, Elliehausen, and Kennickell (1988).

53. Avery, Elliehausen, and Kennickell (1988).

54. See Avery, Elliehausen, and Kennickell (1988, table 2). The income underreporting problem on the CPS is discussed in U.S. Bureau of the Census (1989).

55. Pearl $(1978,1979)$ and Gieseman (1987). 
Table A2. Per Capita Income, Consumption, and Saving in the National Income Accounts and Consumer Expenditure Survey, 1972-73 and 1983-84

\begin{tabular}{lrrrrr}
\hline \multicolumn{1}{c}{ Item } & \multicolumn{2}{c}{$\begin{array}{c}\text { NIA per capita } \\
\text { (dollars) }\end{array}$} & & \multicolumn{2}{c}{$\begin{array}{c}\text { Ratio of CES to NIA } \\
\text { (percent) }\end{array}$} \\
\cline { 2 - 3 } \cline { 5 - 6 } & $1972-73$ & $1983-84$ & & $1972-73$ & $1983-84$ \\
\hline Total income & 4,662 & 11,552 & & 90.8 & 84.6 \\
Wages and salaries & 3,197 & 7,429 & & 104.2 & 102.7 \\
Social security & 230 & 742 & & 87.0 & 84.0 \\
Other pensions & 121 & 504 & & 73.6 & 72.0 \\
All other income & 1,114 & 2,877 & & 55.2 & 40.0 \\
Taxes & 839 & 2,181 & & 88.9 & 86.8 \\
Disposable income & 3,823 & 9,371 & & 91.2 & 84.1 \\
Consumption spending and & & & & 85.1 & 8.2 \\
$\quad$ personal interest & 3,507 & 8,963 & & 85.2 & 84.0 \\
Durable goods & 562 & 1,326 & & 90.2 & 72.2 \\
Nondurable goods & 1,523 & 3,542 & & 71.8 & 89.6 \\
Services & 1,322 & 3,810 & 101.7 & 35.1 \\
Personal interest & 100 & 285 & & 39.0 & 169.5 \\
Saving & 316 & 408 & 159.5 & 201.6 \\
Saving rate (percent) & 8.3 & 4.4 & 174.8 &
\end{tabular}

Source: Authors' calculations using NIA and CES data. For full description, see Sabelhaus (1990c).

a. CES per capita amounts are calculated for urban households that remained in the sample for all interviews and provided complete income information. Sample weights of included households are adjusted for attrition bias using homeownership status, race, and age of the head of the household.

b. The 1983-84 CES value of taxes includes personal income taxes estimated by authors.

Census Bureau and BLS analyses of consumption and supplemented them with an analysis of the income reported in the CES.

Table A2 shows per capita levels of income, consumption, and saving in the national income accounts. It also shows how closely average income and consumption responses in the CES match the per capita levels recorded in the national accounts. All items, except for taxes, appear to be more poorly reported on the 1983-84 CES than on the 197273 CES. Wages and salaries, social security, and other pensions are approximately as well reported in the 1980 s as in the 1970 s, but most other sources of income, especially income from capital and selfemployment, are more poorly reported in the later surveys. Consumption spending also suffers from less accurate reporting in the 1980s surveys, but because the proportional rise in underreporting of income was even larger, the saving rate appears to fall sharply.

The statistics shown in table A2 can be used to evaluate the potential effects of misreporting. For example, the CES saving rate in the 197273 period was 14.4 percent. ${ }^{56}$ If the NIA saving rate is viewed as the

56. For two reasons this saving rate will not exactly correspond to the CES saving rate shown in the main text. First, the saving rates reported in table A2 include households 
correct estimate of the aggregate saving rate, the estimate of saving from the CES would have declined between 1972-73 and 1984 simply because of greater underreporting of income relative to consumption. If CES households had underreported their consumption and income by the same percentage in 1972-73 as they did in 1983-84, the observed saving rate in the 1972-73 period would have been just 12.5 percent, 1.9 percentage points below the rate actually recorded by the CES. The saving rate observed in the 1983-84 CES was 8.9 percent-5.5 percentage points below the rate recorded in the 1972-73 CES. Thus, approximately a third of the decline is attributable to the changing pattern of income and consumption misreporting. About two-thirds of the decline is due to a genuine drop in saving. The CES apparently captures the decline in personal saving, but exaggerates its size. Statistics on saving derived from the CES should be interpreted with this limitation in mind.

Table A3 supplements the information in table A2 by showing a comparison of the age distribution of income reported in the CES and CPS. The income figures in the 1973-74 CES closely match those in the 1973-74 CPS. The correspondence between the two surveys is not as good in 1984. The falloff in the quality of CES income data is particularly severe in the case of households headed by someone over the age of 45 . This conclusion corresponds to our earlier finding that self-employment income and income from capital were more poorly reported on the CES in the 1980s than in the 1970s. Older people typically derive more of their income from self-employment and returns on capital.

The CES/CPS ratios shown in table A3 suggest the possibility of a bias in measuring the change in saving among older age groups. Sabelhaus considered this possibility in a recent study. ${ }^{57}$ Making suitable adjustments for the apparent underreporting of different elements of income and consumption, he showed that the adjusted CES data imply a reduction in the saving rate of all age groups between the 1972-73 period and the early $1980 \mathrm{~s}$, with the exception of the oldest age group.

Finally, tables A4-A6 present the standard errors of the saving rates computed for various subgroups recorded in the CES and SCF data. As

headed by someone under the age of 25 , whereas the text tables exclude such households. Second, to make the CES data precisely match those in the NIA, we have restricted our sample in table A2 to CES households that provided income and consumption data for calendar years 1983 and 1984. The sample analyzed in the text includes households reporting income and consumption for the period 1982-85.

57. Sabelhaus (1990b). 


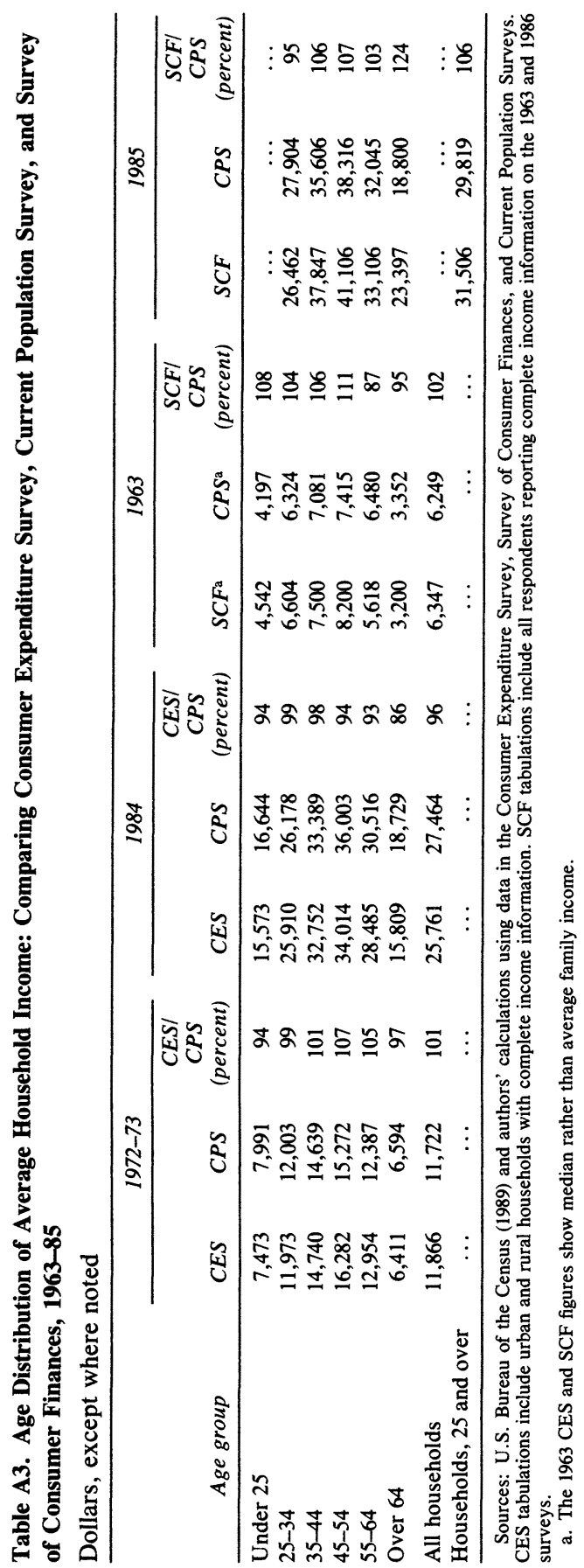




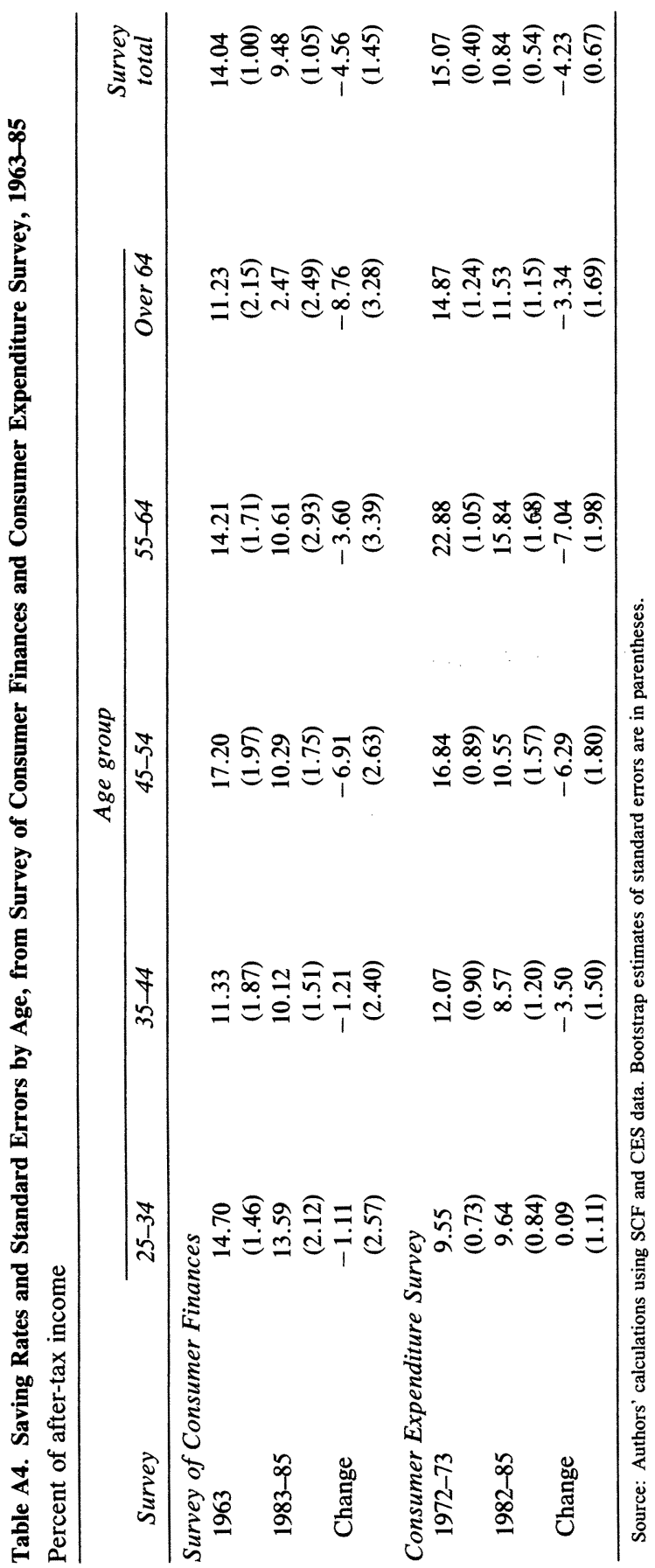


Table A5. Saving Rates and Standard Errors by Income, from Survey of Consumer Finances and Consumer Expenditure Survey, 1963-85

Percent of after-tax income

\begin{tabular}{|c|c|c|c|c|c|c|}
\hline \multirow[b]{2}{*}{ Survey } & \multicolumn{5}{|c|}{ Income quintile } & \multirow[b]{2}{*}{ Total } \\
\hline & $\begin{array}{c}\text { First } \\
\text { (bottom) }\end{array}$ & Second & Middle & Fourth & $\begin{array}{l}\text { Fifth } \\
\text { (top) }\end{array}$ & \\
\hline \multicolumn{7}{|c|}{ Survey of Consumer Finances } \\
\hline 1963 & $\begin{array}{c}-0.31 \\
(2.05)\end{array}$ & $\begin{array}{c}7.93 \\
(2.31)\end{array}$ & $\begin{array}{l}15.36 \\
(1.36)\end{array}$ & $\begin{array}{l}13.48 \\
(1.34)\end{array}$ & $\begin{array}{l}16.51 \\
(1.57)\end{array}$ & $\begin{array}{l}14.04 \\
(1.00)\end{array}$ \\
\hline $1983-85$ & $\begin{array}{r}-2.36 \\
(2.56)\end{array}$ & $\begin{array}{r}-2.91 \\
(1.81)\end{array}$ & $\begin{array}{l}10.00 \\
(2.75)\end{array}$ & $\begin{array}{c}9.87 \\
(1.75)\end{array}$ & $\begin{array}{l}12.45 \\
(1.39)\end{array}$ & $\begin{array}{c}9.48 \\
(1.05)\end{array}$ \\
\hline Change & $\begin{array}{c}-2.05 \\
(3.28)\end{array}$ & $\begin{array}{r}-10.84 \\
(2.93)\end{array}$ & $\begin{array}{r}-5.36 \\
(3.07)\end{array}$ & $\begin{array}{r}-3.61 \\
(2.21)\end{array}$ & $\begin{array}{r}-4.06 \\
(2.09)\end{array}$ & $\begin{array}{r}-4.56 \\
(1.45)\end{array}$ \\
\hline \multicolumn{7}{|c|}{ Consumer Expenditure Survey } \\
\hline $1972-73$ & $\begin{array}{r}-45.39 \\
(2.22)\end{array}$ & $\begin{array}{r}-1.49 \\
(1.07)\end{array}$ & $\begin{array}{c}9.00 \\
(0.73)\end{array}$ & $\begin{array}{l}17.54 \\
(0.51)\end{array}$ & $\begin{array}{l}28.64 \\
(0.64)\end{array}$ & $\begin{array}{l}15.07 \\
(0.40)\end{array}$ \\
\hline $1982-85$ & $\begin{array}{r}-92.09 \\
(5.66)\end{array}$ & $\begin{array}{r}-10.25 \\
(1.32)\end{array}$ & $\begin{array}{c}8.68 \\
(0.84)\end{array}$ & $\begin{array}{l}16.68 \\
(0.74)\end{array}$ & $\begin{array}{l}25.81 \\
(0.75)\end{array}$ & $\begin{array}{l}10.84 \\
(0.54)\end{array}$ \\
\hline Change & $\begin{array}{r}-46.70 \\
(6.08)\end{array}$ & $\begin{array}{r}-8.76 \\
(1.70)\end{array}$ & $\begin{array}{r}-0.32 \\
(1.11)\end{array}$ & $\begin{array}{r}-0.86 \\
(0.90)\end{array}$ & $\begin{array}{r}-2.83 \\
(0.98)\end{array}$ & $\begin{array}{r}-4.23 \\
(0.67)\end{array}$ \\
\hline
\end{tabular}

Source: Authors' calculations using SCF and CES data. Bootstrap estimates of standard errors are in parentheses.

Table A6. Saving Rates and Standard Errors by Asset Ownership, from Survey of Consumer Finances and Consumer Expenditure Survey, 1963-85

Percent of after-tax income

\begin{tabular}{|c|c|c|c|c|c|}
\hline \multirow[b]{2}{*}{ Survey } & \multicolumn{2}{|c|}{ Stock- or bondholder } & \multicolumn{2}{|c|}{ Homeowner } & \multirow[b]{2}{*}{ Total } \\
\hline & Yes & No & Yes & No & \\
\hline \multicolumn{6}{|c|}{ Survey of Consumer Finances } \\
\hline 1963 & $\begin{array}{l}15.55 \\
(1.50)\end{array}$ & $\begin{array}{l}12.65 \\
(0.98)\end{array}$ & $\begin{array}{l}15.24 \\
(1.03)\end{array}$ & $\begin{array}{l}11.48 \\
(1.03)\end{array}$ & $\begin{array}{l}14.04 \\
(1.00)\end{array}$ \\
\hline $1983-85$ & $\begin{array}{l}11.47 \\
(1.85)\end{array}$ & $\begin{array}{c}7.82 \\
(0.82)\end{array}$ & $\begin{array}{c}8.95 \\
(1.12)\end{array}$ & $\begin{array}{l}10.99 \\
(2.11)\end{array}$ & $\begin{array}{c}9.48 \\
(1.05)\end{array}$ \\
\hline Change & $\begin{array}{c}-4.08 \\
(2.39)\end{array}$ & $\begin{array}{c}-4.83 \\
(1.27)\end{array}$ & $\begin{array}{c}-6.29 \\
(1.53)\end{array}$ & $\begin{array}{c}-0.49 \\
(2.35)\end{array}$ & $\begin{array}{r}-4.56 \\
(1.45)\end{array}$ \\
\hline \multicolumn{6}{|c|}{ Consumer Expenditure Survey } \\
\hline $1972-73$ & $\begin{array}{c}20.15 \\
(0.53)\end{array}$ & $\begin{array}{l}10.73 \\
(0.61)\end{array}$ & $\begin{array}{l}17.60 \\
(0.53)\end{array}$ & $\begin{array}{c}8.99 \\
(0.81)\end{array}$ & $\begin{array}{l}15.07 \\
(0.40)\end{array}$ \\
\hline $1982-85$ & $\begin{array}{l}15.76 \\
(0.79)\end{array}$ & $\begin{array}{c}8.17 \\
(0.71)\end{array}$ & $\begin{array}{l}12.08 \\
(0.66)\end{array}$ & $\begin{array}{c}7.08 \\
(0.84)\end{array}$ & $\begin{array}{l}10.84 \\
(0.54)\end{array}$ \\
\hline Change & $\begin{array}{r}-4.39 \\
(0.95)\end{array}$ & $\begin{array}{r}-2.56 \\
(0.94)\end{array}$ & $\begin{array}{c}-5.52 \\
(0.85)\end{array}$ & $\begin{array}{r}-1.91 \\
(1.17)\end{array}$ & $\begin{array}{c}-4.23 \\
(0.67)\end{array}$ \\
\hline
\end{tabular}

Source: Authors' calculations using SCF and CES data. Bootstrap estimates of standard errors are in parentheses. 
mentioned earlier, we employ the bootstrap method to estimate the standard errors because direct computation of variability is problematical. Table A4 shows that across age subgroups the standard error of the saving rate is larger in the SCF sample than in the CES. Differences in saving rates between the two survey dates are statistically significant, however, for all but the youngest age groups. The results in tables A5 and A6, which describe the effects of income and asset ownership, while more mixed, also hold to this general pattern-the standard errors for the SCF data are larger than those for the CES data, but most changes between survey dates are statistically significant. 


\section{Comments and Discussion}

James M. Poterba: Many papers have documented the decline in national saving in the United States and other developed nations during the last decade. Although some analysts have attributed this change largely to fiscal policy, both personal and government saving have declined relative to GNP during this period. This paper by Barry Bosworth, Gary Burtless, and John Sabelhaus tackles the difficult problem of explaining the changes in household saving rates. It rejects some explanations of the decline, such as shifting demographics, and provides a substantial body of evidence that is consistent with many different explanations. One hypothesis the authors stress, because saving rates for homeowners fell faster than those for nonhomeowners, is the possibility that homeowners were consuming their accumulated capital gains on housing during the 1980 s and thereby depressed personal saving. My comments will focus on evaluating how the new evidence on household saving rates affects the plausibility of various explanations for the falling saving rate. I will also address the question of housing wealth and saving behavior in some detail.

The one hypothesis that this paper clearly rejects-the view that shifting demographics explain falling saving — could be rejected in many ways, even without this paper. If differences in age-specific saving rates are relatively small, a rejection of demographic causes follows immediately, particularly because demographic changes have been relatively small over the period of falling saving rates. ${ }^{1}$ Unfortunately, other explanations of the saving decline cannot be refuted or supported so readily.

The authors uncover three stylized facts about personal saving in the

1. This argument is developed in more detail by Summers and Carroll (1987). 
United States over the last few decades: (1) saving rates for all age groups have declined; (2) saving rates for young households have declined less than saving rates for older households; and (3) saving rates of homeowners have declined by more than saving rates of renters. These findings can be used to evaluate the four leading explanations of the saving decline.

First, the declining need for old-age income security may have led to the saving decline. The finding of larger saving reductions among households in the traditional retirement saving years, ages 45-65, provides important support for this view. In 1970 the poverty rate for elderly Americans was 2.2 times the national poverty rate. By the late 1980 s, however, the poverty rate was lower among elderly Americans than among younger households. The increasing generosity of social security and the diffusion of private pension plans have raised the standard of living for elderly households, resulting in less need for traditional personal saving for retirement.

The second explanation concerns the reduced need for precautionary saving. This explanation overlaps in part with the previous one, since an important motive for precautionary saving may be the provision of health care during old age. Despite cries about the uninsured population in the United States, a higher share of individuals are covered by insurance today than in the past. The safety net for some catastrophic needs, notably medical emergencies, has become tighter over time. This may have reduced household incentives for precautionary saving. Which age groups would be most directly affected? Older households for medical emergencies, but younger households for disability or other risks that reduce income potential.

The third explanation considers the reduced need for "target saving" to be a result of easier access to credit. The sharp increase in consumer credit relative to income (if not assets) in the early 1980s, as well as the apparent decline in some measures of accumulation such as downpayment levels by first-time homebuyers, suggests that households may need to do less saving before major purchases. This could contribute to reduced saving among younger households, but should have relatively little effect on older households with substantial accumulated wealth. The rise of credit lines backed by home equity, one example of increased credit access, could have a particularly important effect on older households with the most substantial housing assets.

The final explanation concerns the receipt of cash payments, not 
classified as income, from corporate control transactions. These transactions totaled nearly $\$ 100$ billion a year by the end of the decade, providing a stimulus to consumption that does not show up as income. Household surveys may include capital gains as a component of income, but they do not show the cash received by households when selling assets. The national accounts even exclude capital gains from household income. If these cash receipts spur consumption, the saving rate will fall because there will be no income flow corresponding to these items. The time series correlation between household cash receipts and real consumption levels is quite high, but is difficult to interpret as causal. ${ }^{2}$ Further evidence on the importance of this effect requires careful analysis of very high income and high wealth households.

The most suggestive finding in the Bosworth, Burtless, and Sabelhaus paper is that saving rates for homeowners have fallen by more than saving rates for nonhomeowners. This raises the important question of whether the 30 percent increase in real house values during the 1970s could explain the low U.S. personal saving rate of the 1980s. Initially, one should be clear that the benchmark for the consumption response to housing capital gains is substantially smaller than for other capital gains. When house prices rise, the user cost of housing facing households rises too. If the household lived forever and was planning to live in the current house forever, then the price appreciation precisely offsets the higher user charges in perpetuity and there is no net effect on household spending. Only when a household plans to "trade down" to another unit, or to move to another city with lower house prices, does a change in the local price correspond to a windfall gain.

The disparity between homeowner and renter saving rates could be due either to unusually low saving rates among homeowners or to high saving rates among renters. This paper suggests that saving rates for all groups are low and have fallen, but the question is whether changes in house prices have exacerbated the saving decline among owners or limited the decline among renters. A recent study of renter saving rates across cities ${ }^{3}$ finds convincing support for the view that renter households in high-house-price cities save a higher fraction of their income than their counterparts in other places. Higher house prices raise " target

2. Evidence on this issue is provided in Hatsopoulos, Krugman, and Poterba (1989).

3. Sheiner (1989). 
saving" in this part of the life cycle, and thus may have contributed to smaller-than-otherwise declines in saving rates for renters.

This paper's statistical evidence on housing capital gains and consumption is in effect a regression of the household saving rate on a dummy variable for homeownership. More refined tests are possible, using for example the amount of housing gain available to different households. A number of previous studies have tried to identify the link between house prices and consumer spending using such tests. Jonathan Skinner's work is notable, since he uses the Panel Survey of Income Dynamics (PSID) data on estimated house value and purchase price to construct a measure of accrued capital gain. ${ }^{4}$ His work suggests a relatively weak link between the increase in house values and the decline of household saving. However, his analysis relies on the unfortunately limited consumption data of the PSID and focuses on the late 1970s, a period before the rapid increase in second mortgages and home equity credit lines. The findings in the current study are a tantalizing lure to further research in this area.

The paper does disaggregate homeowners by age and finds larger declines in saving rates for older homeowner households than for younger ones. The evidence from the Survey of Consumer Finances and the Consumer Expenditure Survey is somewhat contradictory on whether the elderly homeowners have experienced sharper saving declines than others, but both surveys suggest smaller saving changes for young homeowners than for those aged 45 and over. The largest potential effects of changing house prices are for elderly households. More than 85 percent of U.S. households own their homes when they reach age 60 , and most will have paid off or nearly paid off their mortgages.

Several stylized facts nevertheless suggest relatively limited consumption responses among these groups. First, most of the "young elderly," those aged $65-74$, tend to remain in the house they owned at retirement. ${ }^{5}$ There is weak evidence that in the few years before death or after the death of a spouse, mobility rates increase. Second, when these households are offered the opportunity to borrow against their homes, they show remarkably little willingness to do so. Trial programs with reverse annuity mortgages, for example, suggest that households

4. Skinner (1989).

5. An important data source on the housing behavior of the elderly is Sheiner and Weil (1990). 
wish to preserve their home equity. This suggests that housing wealth may be viewed as an imperfect substitute for other types of wealth, and that households are less likely to use housing wealth to finance retirement consumption.

The links between housing, credit institutions, and saving behavior could potentially be identified by analyzing household behavior in different countries or even in different parts of the United States, but such research will require substantial detail on household characteristics and circumstances. The present paper makes important progress and will surely stimulate further work.

Lawrence H. Summers: This paper by Barry Bosworth, Gary Burtless, and John Sabelhaus is a terrific example of a classic Brookings genre: the study of ratios that have traditionally been either declining or increasing at a relatively steady rate. Almost always, the object of the study is a ratio of substantial social consequence. Typically, the authors first observe that changes in the ratio are not a figment of measurement error. The authors usually wonder whether movements can be explained through shifting composition within and across categories. Normally they find that more of the action occurs within categories than across categories. George Perry's work on the unemployment rate is the exception that proves this rule. These typical authors then consider a number of strong monocausal explanations that other economists have suggested; they reject them point by point. They then observe that the phenomenon is important, but somewhat mysterious, and the discussion goes down in a blaze of amateur sociology which attempts to look for the general, systemic, and unfavorable factor that has accounted for the change. Knowledge is in the end enriched by the discussants, by the authors, and by the rejection of the monocausal explanations.

I think we are seeing that pattern strengthen as time passes. Computer technology has marched on and data have become more available. The odds that microdata will play a role in the rejection process have increased. That is the case here today.

I want to talk first about five hypotheses that the authors, in one way or another, touch on and subsequently reject. Then I would like to talk about some possible explanations that may account for the decline in saving rates. 
Before doing that, I would note parenthetically that the authors point out something important, a fact that anyone examining these microdata should notice: while macroeconomists have taken to conceptualizing the study of consumption behavior in terms of permanent-income individuals and other, liquidity-constrained, individuals, who spend all their income each year, a look at the microdata reveals that this hypothesis is all wrong. First, hardly any families spend exactly their income; and second, there is an enormous range of variation in saving, which means that the nonpermanent-income people should not be modeled as people who spend their entire income.

Turning to the subjects that the authors take up, I first look at the demography side. The authors make a point that has been made before, that a Perry-weighted saving rate looks the same as a regular saving rate. Yet the idea that the aging of the population could matter seems supported by saving behavior in Asian countries, which have little social support for the elderly.

David Weil has proposed an interesting reconciliation of those two ideas. ${ }^{1}$ His research suggests that there is a kind of general equilibrium effect that has to be taken into account. In a population where there are many 65 -year-olds, there may also be many 39 -year-olds who think they will be getting bequests soon, and are consuming in anticipation of them. There may also be many 39-year-olds who are taking care of their aged parents and are feeling the burden of that. And there may be a lot of 65year-olds who are making gifts to their grandchildren.

Weil provides some evidence that is consistent with this view of important intergenerational bequests. It is one possible rationalization for the negative demographic finding, but it is a demographic channel that the authors do not explore.

Some people have argued that the baby boom generation will save more as they move into a high saving age, and that, therefore, national saving is going to rise seven or eight years from now. My best guess is that the change in demographic composition will not have a large impact on the saving rate.

Turning to another subject the authors consider, housing, I think Jim Poterba got the microeconomics of this basically right in the foregoing discussion. The key point is to recognize that there is a difference

1. Weil (1990). 
between my house going up relative to everybody else's house and all houses going up. If all houses go up and you are determined to live in a house, that is not such good news and should not be expected to lead to a large increase in the saving rate.

At one point Chris Carroll and I looked at the Consumer Expenditure Survey without the refinements the authors have made-it was therefore much cruder data. We looked at whether there had been important changes in saving rates in the Midwest relative to the coastal parts of the country, with a view toward seeing whether housing prices were important to saving. We found no evidence to support that hypothesis.

In Japan, it is commonly said that house prices are so high that people have to save to buy a house and that high house prices are therefore an explanation for high saving rates. I think it is a mistake to suppose that there is any obvious link there. Furthermore, if I understand the facts, real house prices in the United States had their most dramatic period of increase in the late 1970s, not during the 1980s. So, the timing evidence is not quite right for house prices to explain the low saving rate. Rather than focusing on the role of house prices, it might be more fruitful to emphasize those changes in capital markets that allow more people to take second houses and to buy houses with lower downpaymentsdevelopments that have changed people's ability to borrow.

In a somewhat related vein, I was surprised that we were not reminded that a low saving rate in the 1980s had coincided with record high real interest rates. It is fair to observe that, if a mystery factor has caused the decline in saving rates, one would expect to see a pattern in which real interest rates rose and the saving rate fell. Because it has been supposed that some mystery factor has been reducing saving, one would not take that pattern as evidence that a ceteribus paribus change in real interest rates might be having an effect on saving rates.

In yet another potential explanation, the authors discuss the accelerator notion in connection with saving, which is very appealing. However, it does not have-and the authors do not give it-much of a microeconomic foundation in terms of preferences and utility functions and the like. One is tempted by the view that if saving has a precautionary character, income growth will map into a change in saving rates. Of course, how large a precautionary balance I want to have on hand will depend upon what my expected future income prospects are. So, while the target wealth-income ratio idea is plausible, it has not been given a 
story in terms of microeconomic preferences. Furthermore, the fact that capital gains seem to have relatively little to do with saving behavior poses a problem for the view that the target wealth-income ratio is important to saving, or at least that it is important at all levels of income.

On the growth-saving nexus, there seem to be at least two ideas worth considering when explaining why growth and private saving go together to the extent they do. One is that the rate of growth of income may affect the target growth rate of consumption. If my aspirations for when I am 65 years old are to live as well as a 40 -year-old professor lives, rather than have some absolute standard of living in mind, an increase in the growth rate of consumption may increase my saving rate.

An alternative notion, supporting the same conclusion, is that people are very slow to adjust their standard of living; and that when income growth is fast, people respond like first-year assistant professors-they still look like graduate students and they have high saving rates. In countries where income is growing rapidly, that is what always happens; a lot, therefore, have high saving rates.

I do not think we have a firm story for this accelerator notion of saving, and I am not sure just how hard we should look. I was surprised when I examined, a couple of years ago, cross-country evidence and found that the strong relationship between the slowdown in growth and the change in the national saving rate was heavily driven by deficits, rather than by private saving. When one looks at private saving, that relationship is not strong. The United States has actually not undergone one of the larger slowdowns in the world. Yet it has undergone one of the larger slowdowns in private saving.

Finally, to highlight one of the things that is implicit in the authors' discussion, the evil-1980s hypothesis finds little comfort in these data. There is the loose notion that all the junk bonds, all the restructuring, and all the realizing of capital gains are responsible for the decline in saving. The cross-country data suggest, however, that busy investment bankers are not the primary cause for what has been happening to saving. The pattern of declining saving is common to other countries and, more importantly, it is common among young people and people in the lower parts of the income distribution, who are quite unlikely to be receiving takeover premiums or interest on junk bonds.

What general hypotheses might explain the movements in saving? Let me comment on four possible explanations. The hypothesis that 
Carroll and I presented a couple of years ago-which I still think has a lot to do with what is going on, although it is difficult to prove-is that progress means that people have less to worry about than they used to, and because they have less to worry about they have a lower need to save. ${ }^{2}$ Twenty-five years ago the poverty rate among the elderly was twice what it is today: then, the poverty of older Americans was twice the rate of younger citizens. Today, the poverty rate is higher for those under 65 than for those over 65. My guess is that many more people form a view about retirement by looking at whether their parents seem rich or poor, than by looking at the report of the social security actuaries.

In the same vein, the incidence of life insurance is larger than what it once was. Also, ability to borrow for short-term credit is greater than it once was. It seems plausible that, in general, people have less to worry about, and, therefore, they feel less need to save.

A second related hypothesis is that better capital markets mean fewer people are liquidity constrained and more people can borrow. As a consequence, the people who are less liquidity constrained are consuming more, and their saving rate is lower.

If I understand the nature of the authors' data, this is potentially a testable hypothesis. If this hypothesis were wrong and if the general tone that the authors maintain is correct, one would expect that a symmetric distribution of saving rates would have simply slid to the left in the 1980s. If, on the other hand, the capital markets have changed and people are more likely to borrow, an elongation of the negative tail would appear and would account for a significant part of the movement. Unfortunately my guess is that it will not be possible to prove whether the shape of the distribution has changed.

Finally, I would like to allude to some findings by Joel Slemrod. ${ }^{3}$ His rather straightforward hypothesis-which he explores using cross-sectional and time-series data-is that people's feeling of security has something to do with the amount that they save. He puts this hypothesis, however, to an unconventional test: he shows that saving behavior is correlated with both time-series and cross-sectional measures of the perceived likelihood of nuclear war. The time series is the changing prospect of nuclear war as measured by the Union of Concerned

2. Carroll and Summers (1989).

3. Slemrod $(1982,1990)$. 
Scientists. The cross-sectional data are the findings of public opinion polls in several countries on the likelihood of nuclear war.

Obviously, his findings do not fit with the usual idea about how and why people save. I would add, however, as very weak anecdotal evidence, the prominent economist who once worked in the Pentagon and who announced to my parents in 1960 that he did not have a pension because, given the prospect of nuclear war, he did not think he would be around to enjoy it. Presumably he has reformed his behavior, since he will soon be needing his pension after all.

Is it less plausible to believe that many people save less because they think there will be a nuclear war, than to believe that many people save more because they anticipate that their children will be more heavily burdened by the government debt? The latter hypothesis, for which I think it is difficult to produce graphs as compelling as Slemrod's, seems to have been taken very seriously. Why not give some more credence to a proven statistical relationship between saving and the prospect of nuclear war?

\section{General Discussion}

Several of the panelists thought that the saving decline across age groups was less uniform than suggested by the authors. George Perry and Robert Gordon observed that tables 3 and 5 show a much faster decline in saving in the 45 -and-older age groups. They suggested that focusing on the distinctive characteristics of this group might be informative. Gordon observed that young people save for rainy days or downpayments and thus have short horizons while older people are saving for retirement. Hence saving in different age groups might be expected to differ in response-for example, to changes in social security. William Brainard agreed and noted that many individuals attempt to achieve a level of retirement income proportional to their preretirement income. In that case a slowdown in growth and higher interest rates would help explain a decline in saving for retirement.

Christopher Sims observed that the ability of the life-cycle model to explain the decline in saving depends upon whether GNP growth is better modeled as stationary fluctuations around trend or drifting nonstationarity. While the authors treat the low growth of the late 1970s and 
1980 s as anticipated, it is not clear that a rational person in the late seventies would have done so. It would have been natural for him to assume that a few years of slow growth were bad luck and that income would return to trend: Since the level of saving would fall with income below trend, a period of slow growth would be expected to have low saving. This effect would be compounded by lifestyle inertia. People make commitments to houses, cars, private schools, and so on that make it costly to change consumption rapidly. Sims noted that this explanation of the decline in saving would predict an eventual return to higher levels of saving as the slow growth is accepted as permanent, in contrast to the authors' accelerator explanation, which predicts a permanent decline in saving with lower growth.

William Nordhaus observed that whereas the data show a greater decline in saving in the oldest age group than in the younger ones, explanations of the decline in saving based on, for example, the income effect of a rise in interest rates, to the extent that they are part of a zerobequest life-cycle model, would predict that saving should go down least in the oldest group. Changes in lifetime income expectations should have an effect proportional to the fraction of the lifetime remaining. The only explanations that predict a comparable decline across age groups are clan-type arguments in which individuals behave as if they are infinitely long-lived.

Nordhaus also expressed some concern about the sensitivity of the results to the imputations and adjustments necessary to get from a cash concept of saving to a national income accounts concept. The peaks and troughs can be changed and the saving rate decline can even be made to disappear by appropriate readjustments. He also noted that while many countries experienced declines in saving after 1973, they do not have a great deal of cyclical coincidence.

The coincidence of the peaks in Canadian saving and oil shocks led Gordon to suggest that the decline in saving may be due to heightened inflationary expectations and anxieties about the future. He cited a paper by Thomas Juster and Paul Wachtel (BPEA, 1:1972) which suggested that an increase in inflation raises saving as people compensate for the erosion of real wealth. A decline in inflationary expectations in the 1980s would be expected to reduce saving.

James Tobin reported the results of a recent survey of the Harvard class of 1939 that illuminated the saving behavior of the elderly. While 
they are an affluent group, the behavior of the affluent is an important determinant of overall saving. They were all expecting to live on their pensions and never touch any other part of their wealth, which they planned to leave to their children. There seemed to be very little concern about living so long, and in such a decrepit condition, that they would not be able to manage their medical expenses. They did not expect they would ever need to ask their children for any help.

Robert Litan presented two pieces of evidence against and for Lawrence Summers's contention that people feel more secure now than they did 10 to 15 years ago. There is an abundance of survey evidence that young people no longer think they will receive social security benefits when they retire and there have been cutbacks at the state level in unemployment insurance. He noted, however, that there is much less stigma now attached to personal and corporate bankruptcy, so that individuals may borrow more and save less, taking greater bankruptcy risk.

Martin Baily noted that family dissolution has a significant negative impact on saving. He asked if changes in family structure could account for some of the decline. Baily also noted that the perceived likelihood of nuclear war is really only correlated with saving from 1965 to 1970; at other times the fit is not that good. Nordhaus mentioned that a political scientist who investigated the process by which the degrees of likelihood are determined found a significant ratchet effect. The clock is turned forward whenever anything exacerbates international tensions, but there is a reluctance to turn it back when tensions cease. 


\section{References}

Aaron, Henry J., Barry P. Bosworth, and Gary T. Burtless. 1989. Can America Afford to Grow Old? Paying for Social Security. Washington: Brookings.

Auerbach, Alan J., and Laurence J. Kotlikoff. 1989. "Demographics, Fiscal Policy, and U.S. Saving in the 1980s and Beyond." Working Paper 3150. Cambridge, Mass.: National Bureau of Economic Research (October).

Avery, Robert B., and others. 1984. "Survey of Consumer Finances, 1983." Federal Reserve Bulletin 70: 679-92.

Avery, Robert B., Gregory E. Elliehausen, and Arthur B. Kennickell. 1988. "Measuring Wealth With Survey Data: An Evaluation of the 1983 Survey of Consumer Finances." Review of Income and Wealth 34: 339-69.

Bernheim, B. Douglas, and John B. Shoven. 1988. "Pension Funding and Saving." In Pensions in the U.S. Economy, edited by Zvi Bodie, John B. Shoven, and David A. Wise. Chicago: University of Chicago Press.

Boskin, Michael J., and Lawrence J. Lau. 1988a. "An Analysis of Postwar U.S. Consumption and Saving: Part I, The Model and Aggregation." Working Paper 2605. Cambridge, Mass.: National Bureau of Economic Research (June).

. 1988b. “An Analysis of Postwar U.S. Consumption and Saving: Part II, Empirical Results.' Working Paper 2606. Cambridge, Mass.: National Bureau of Economic Research (June).

Bosworth, Barry. 1989. "Institutional Change and the Efficacy of Monetary Policy." BPEA, 1:1989, 77-110.

- 1990. "The Global Decline in Saving: Some International Comparisons." Brookings Discussion Papers in International Economics 83. Washington: Brookings (December).

Bosworth, Barry, and Gary Burtless. 1990. "Effects of Tax Reform on Labor Supply, Investment, and Saving." Washington: Brookings (December).

Bradford, David F. 1990. "What is National Saving? Alternative Measures in Historical and International Context." In The U.S. Saving Challenge: Policy Options for Productivity and Growth, edited by Charles E. Walker, Mark A. Bloomfield, and Margo Thorning. Boulder, Colo.: Westview Press.

Bureau of Labor Statistics. 1989. Consumer Expenditure Interview Survey: Quarterly Data, 1984-87. Bureau of Labor Statistics Bulletin 2332. Washington: U.S. Department of Labor.

Carroll, Chris, and Lawrence H. Summers. 1989. "Consumption Growth Parallels Income Growth: Some New Evidence." Working Paper 3090. Cambridge, Mass.: National Bureau of Economic Research (September).

Cutler, David M., and others. 1990. "An Aging Society: Opportunity or Challenge?" BPEA, 1:1990, 1-56.

Efron, Brad, and R. Tibshirani. 1986. "Bootstrap Methods for Standard Errors, Confidence Intervals, and Other Measures of Statistical Accuracy." Statistical Science 1: 54-75.

Engelhardt, Gary V., and James M. Poterba. 1990. "Housing Prices and 
Demographic Change: Canadian Evidence.' Unpublished paper, Massachusetts Institute of Technology (December).

Farrell, M. J. 1970. "'The Magnitude of 'Rate-of-Growth' Effects on Aggregate Saving." Economic Journal 80: 874-94.

Feldstein, Martin. 1980. "International Differences in Social Security and Saving." Journal of Public Economics 14: 225-44.

Gieseman, Raymond. 1987. "'The Consumer Expenditure Survey: Quality Control by Comparative Analysis." Monthly Labor Review 110 (March): 8-14.

Hall, Robert E., and F. S. Mishkin. 1982. "The Sensitivity of Consumption to Transitory Income: Estimates from Panel Data on Households.' Econometrica 50: 461-82.

Hatsopoulos, George N., Paul R. Krugman, and James M. Poterba. 1989. Overconsumption: The Challenge to U.S. Economic Policy. Washington: American Business Conference.

Horioka, Charles Yuji. 1989a. "Why is Japan's Private Saving Rate So High?" In Developments in Japanese Economics, edited by Ryuzo Sato and Takashi Negishi. Tokyo: Academic Press.

- 1989b. “The Determinants of Japan's Saving Rate: The Impact of the Age Structure of the Population and Other Factors.' Discussion Paper 189. Osaka: Institute of Social and Economic Research, Osaka University (June).

Household Surveys Division. 1986. Family Expenditure in Canada. Ottawa: Statistics Canada.

Management and Coordination Agency. Various years. Annual Report on the Family Saving Survey. Tokyo: Statistic Bureau.

- 1988. Comprehensive Time Series Report on the Family Income and Expenditure Survey, 1947-1986. Tokyo: Statistic Bureau.

Manchester, Joyce M., and James M. Poterba. 1989. "Second Mortgages and Household Saving." Working Paper 2853. Cambridge, Mass.: National Bureau of Economic Research (February).

Masson, Paul R., and Ralph W. Tyron. 1990. "Macroeconomic Effects of Projected Population Aging in Industrial Countries.' IMF Staff Papers 37: 453-85.

Modigliani, Franco. 1966. "The Life Cycle Hypothesis of Saving, the Demand for Wealth and the Supply of Capital." Social Research 33: 160-217.

1970. "The Life Cycle Hypothesis of Saving and Intercountry Differences in the Saving Ratio." In Induction, Growth, and Trade: Essays in Honor of Sir Roy Harrod, edited by W. A. Eltis, M. FG. Scot, and J. N. Wolfe. New York: Oxford University Press.

Modigliani, Franco, and Arlie Sterling. 1983. "Determinants of Private Saving with Special Reference to the Role of Social Security-Cross-country Tests.' In The Determinants of National Saving and Wealth, edited by Franco Modigliani and Richard Hemming. New York: St. Martin's Press.

Pearl, Robert B. 1978. The 1972-1973 U.S. Consumer Expenditure Survey: A Preliminary Evaluation. U.S. Bureau of the Census Technical Paper 45. Washington: Government Printing Office. 1979. Reevaluation of the 1972-73 U.S. Consumer Expenditure Survey: 
A Further Examination Based on Revised Estimates of Personal Consumer Expenditures. U.S. Bureau of the Census Technical Paper 46. Washington: Government Printing Office.

Pension and Welfare Benefits Administration. 1989. Trends in Pensions. Washington: U.S. Department of Labor.

Projector, Dorothy S. 1968. Survey of Changes in Family Finances. Washington: Board of Governors of the Federal Reserve System.

Projector, Dorothy S., and Gertrude S. Weiss. 1966. Survey of Financial Characteristics of Consumers. Washington: Board of Governors of the Federal Reserve System.

Sabelhaus, John. 1990a. "Development and Usage of the Consumer Expenditure Survey (CEX) Consumption, Income, and Wealth Data Set." Unpublished paper, Brookings and Towson State University, Towson, Md. (September).

- 1990b. "Did Demographics Lower the Household Saving Rate?" Unpublished paper, Brookings and Towson State University, Towson, Md. (October).

- 1990c. "Measuring the Secular Decline in U.S. Saving with Survey Data." Unpublished paper, Brookings and Towson State University, Towson, Md. (October).

Sheiner, Louise. 1989. "Housing Prices and the Savings of Renters." Unpublished paper, Harvard University (November).

Sheiner, Louise, and David Weil. 1990. "The Housing Wealth of the Aged." Unpublished paper, Harvard University (August).

Skinner, Jonathan. 1988. "Risky Income, Life Cycle Consumption, and Precautionary Savings." Journal of Monetary Economics 22: 237-55.

- 1989. "Housing Wealth and Aggregate Saving." Working Paper 2842. Cambridge, Mass.: National Bureau of Economic Research (February).

Slemrod, Joel. 1982. "Post-War Capital Accumulation and the Threat of Nuclear War.' Working Paper 887. Cambridge, Mass.: National Bureau of Economic Research (May).

- 1990. "Fear of Nuclear War and Intercountry Differences in the Rate of Saving." Economic Inquiry 28: 647-57.

Summers, Lawrence H., and Chris Carroll. 1987. "Why Is U.S. National Saving So Low?', BPEA, 2:1987, 607-35.

Tobin, James. 1967. "Life Cycle Saving and Balanced Growth." In Ten Economic Studies in the Tradition of Irving Fisher. New York: John Wiley and Sons.

U.S. Bureau of the Census. 1989. Money Income of Households, Families, and Persons in the United States, 1987. Series P-60, No. 162. Washington: Government Printing Office.

Weil, David. 1990. "The Saving of the Elderly in Micro and Macro Data." Ph.D. diss., Harvard University.

Zeldes, Stephen P. 1989. "Optimal Consumption with Stochastic Income: Deviations from Certainty Equivalence." Quarterly Journal of Economics 104: 275-98. 